\title{
The Christmas Cove Dyke of coastal Maine, USA, and regional sources for Early Mesozoic flood basalts in northeastern North America
}

\author{
J. Gregory McHone ${ }^{1 \star}$, Arthur M. Hussey, II², David P. West, JR. ${ }^{3}$, AND \\ DAVID G. BAILEY ${ }^{4}$ \\ 1. 9 Dexters Lane, Grand Manan, New Brunswick E5G3A6, Canada \\ 2. Department of Earth and Oceanographic Science, Bowdoin College, Brunswick, Maine 04011 USA \\ 3. Department of Geology, Middlebury College, Vermont 05753 USA \\ 4. Department of Geosciences, Hamilton College, Clinton, New York 13323 USA \\ ^Corresponding author < greg@earth2geologists.net>
}

Received 22 January 2014 gaccepted 04 March 2014

\begin{abstract}
A large Early Mesozoic quartz tholeiite dyke has been mapped discontinuously for $190 \mathrm{~km}$ in southern coastal Maine, USA. Including its type locality at Christmas Cove (South Bristol, Maine, USA), the dyke has features of a generally ENE strike; dip usually steep to the SSE but abruptly turning very shallow in short sections; and widths of 9 to $35 \mathrm{~m}$. The dyke rock has a distinctive cross-columnar field appearance, and a subophitic to micro-porphyritic texture with abundant Ti-bearing augite, calcic plagioclase, scattered euhedral orthopyroxene phenocrysts, and coarse-grained glomerophyric clumps of augite with plagioclase. Several ${ }^{40} \mathrm{Ar} /{ }^{39} \mathrm{Ar}$ whole-rock dates for this and associated regional dykes are close to $201 \mathrm{Ma}$, in agreement with ages of other Early Mesozoic dykes and basalts of the Central Atlantic Magmatic Province (CAMP). The geographic position, age, wholerock chemistry, and petrography indicate that the Christmas Cove Dyke is co-magmatic or contiguous with the Higganum-Holden Dyke of southern New England, which was a source for the Talcott Basalt of the Early Mesozoic Hartford rift basin. The dyke system is a 700-km long fissure source for the earliest rift basin basalts preserved in northeastern North America, and it virtually connects the Hartford Basin and the Fundy Basin in Atlantic Canada. The Caraquet Dyke of New Brunswick and central Maine may be co-magmatic with the Buttress Dyke and Holyoke Basalt of southern New England, but lava from it is not preserved in Atlantic Canada or Maine.
\end{abstract}

\section{RÉSUMÉ}

Un grand dyke de tholéiite remontant à l’ère Mésozoïque précoce a été cartographié de façon discontinue sur $190 \mathrm{~km}$ sur la côte du Sud du Maine, aux États-Unis. En plus de sa localité type à Christmas Cove (South Bristol, Maine, É.-U.), le dyke possède comme caractéristiques une direction générale E.-N.-E., une descente habituellement raide vers le S.-S.-E. devenant abruptement très peu profonde sur de courtes sections et une largeur variant entre 9 et $35 \mathrm{~m}$. La roche du dyke présente une prismation horizontale particulière et une texture variant de subophitique à microporphyrique abondante en augite contenant du titane, en plagioclase calcique, en phénocristaux d'orthopyroxène idiomorphes dispersés et en amas d'augite glomérophyrique granuleuse avec feldspath plagioclase. Plusieurs dates obtenues par la méthode ${ }^{40} \mathrm{Ar} /{ }^{39} \mathrm{Ar}$ sur roche totale de ce dyke et d'autres dykes liés de la même région s'approchent des $201 \mathrm{Ma}$, ce qui correspond à l'âge d'autres dykes de lère Mésozoïque précoce et du basalte de la province magmatique centre atlantique (PMCA). La position géographique, lâge, la chimie sur roche totale et la pétrographie indiquent que le dyke de Christmas Cove est comagmatique ou contigu à celui de Higganum-Holden du Sud de la Nouvelle-Angleterre, qui 
était l'une des sources du basalte de la montagne Talcott du bassin d'effondrement Hartford de lère Mésozoïque précoce. Le réseau de dykes est une fissure d'une longueur de $700 \mathrm{~km}$ qui serait la source la plus ancienne de basalte de bassin d'effondrement préservée au Nord-Est de l'Amérique du Nord, et il relie pratiquement le bassin Hartford et le bassin Fundy du Canada atlantique. Le dyke de Caraquet du Nouveau-Brunswick et du centre du Maine pourrait être comagmatique au dyke Buttress et au basalte de la chaîne Holyoke du Sud de la Nouvelle-Angleterre, mais aucune lave provenant de ce dyke n'est préservée au Canada atlantique ou au Maine.

[Traduit par la redaction]

\section{INTRODUCTION}

Flood basalt provinces are typically derived from fissure eruptions that produce large volumes of tholeiite over brief time spans, with fluid pahoehoe-type lavas that can flow for great distances (Self et al. 1997; Swanson et al. 1975). Feeder dykes rise through the lithospheric mantle beneath the fissures and are exposed after overlying basalt has been removed by later uplift and erosion, so the connection of particular source dykes with remaining flood basalts may no longer be obvious (McHone 1996). However, regional studies combining field, petrologic, geochemical, and geochronological data have the potential to reveal dykelava flow links, as has been demonstrated for the Early Mesozoic Hartford Basin (Philpotts and Martello 1986) and the Columbia River Basalt Group (Swanson et al.1975). The Christmas Cove Dyke of coastal Maine is a large intrusion of quartz tholeiite that extends between Early Mesozoic rift basins in New England and Atlantic Canada, and as we will show, appears to be co-magmatic with their Late Triassic flood basalts.

The Christmas Cove Dyke was first mapped and described at Harpswell Neck (Hussey 1971), and later in the Portland and Bath 1:100 000-scale bedrock quadrangle maps in northern Casco Bay, Maine (Berry and Hussey 1998; Hussey and Marvinney 2002). Figure 1 shows the general location of the dyke, but the bedrock geologic maps referred to above provide greater detail for the interested reader. The dyke was briefly described at Christmas Cove in South Bristol by Bascom (1899) although she did not trace it beyond that area. At most locations the dyke trends toward its next exposure, but it is not particularly linear (Fig. 1). Distinctive macroscopic and field features are consistent along its great length and distinguish the dyke from numerous older basaltic intrusions of Maine. The Christmas Cove Dyke may continue far to the northeast as well as southwest, but outcrops along its trend are generally poor, and a detailed magnetic survey may be required to trace its full extent.

We also sampled the Caraquet Dyke (Greenough and Papezik 1986) that extends a minimum of $470 \mathrm{~km}$ across New Brunswick (Burke et al. 1973) and into central Maine at least to Macwahoc (Boucot et al. 1964), as located by its distinct and linear aeromagnetic anomaly. Late Triassic to Early Jurassic tholeiitic dykes and basin flood basalts in the region are located in Figure 2.

Our main purpose is to describe the locations, petrography, whole-rock chemistry, and age of the Christmas Cove Dyke, and to compare it to previously described tholeiitic dykes and basalts in the region. Large dykes are sources for basalts in Early Mesozoic rift basins, and they could have produced extensive flows outside of the basins as well (McHone 1996). Petrography, geochemistry, and whole-rock ${ }^{40} \mathrm{Ar} /{ }^{39} \mathrm{Ar}$ radiometric ages can support these genetic links. The spatial distribution of the Christmas Cove and other regional dykes, along with their correlation with basalts in the basins (Fig. 2), provide information about the origin, extent, and timing of major volcanic events of the Central Atlantic Magmatic Province, some of which may be linked to the mass extinction near the Triassic-Jurassic boundary (Schoene et al. 2010; Blackburn et al. 2013).

We visited outcrops of the Christmas Cove Dyke as located by several students and field geologists, by maps by the Maine Geological Survey cited above, and by our own field work. Locations not previously mapped are in a small road cut along Rte. 202/4 at Waterboro, in spectacular shoreline exposures at Whitehead Island (de Boer et al. 2003) and Swans Island (Perry 1994), and as a few outcrops on isolated islands (e.g., Barter Island) found via air photographs and Google Earth. The dyke generally parallels the coastline, crossing much open water in bays and cropping out at shorelines of peninsulas and islands (Fig. 1). Field visits and data collection have been underway by the authors for several decades (Hussey 1971; McHone 1984, 1993; West and McHone 1997) by searching and visiting locations, and conducting thin-section petrography, geochronological studies, and whole-rock chemical analyses. Jelle de Boer and Andrew Lindsey visited several of the same locations to obtain oriented drill cores for a paleomagnetic study of flow direction (de Boer et al. 2003). ${ }^{40} \mathrm{Ar} /{ }^{39} \mathrm{Ar}$ radiometric ages were determined using samples from three locations along the Christmas Cove Dyke, as well as single samples from the Caraquet Dyke near Bancroft, Maine, and the Higganum Dyke at Hurd State Park in Haddam, Connecticut. 


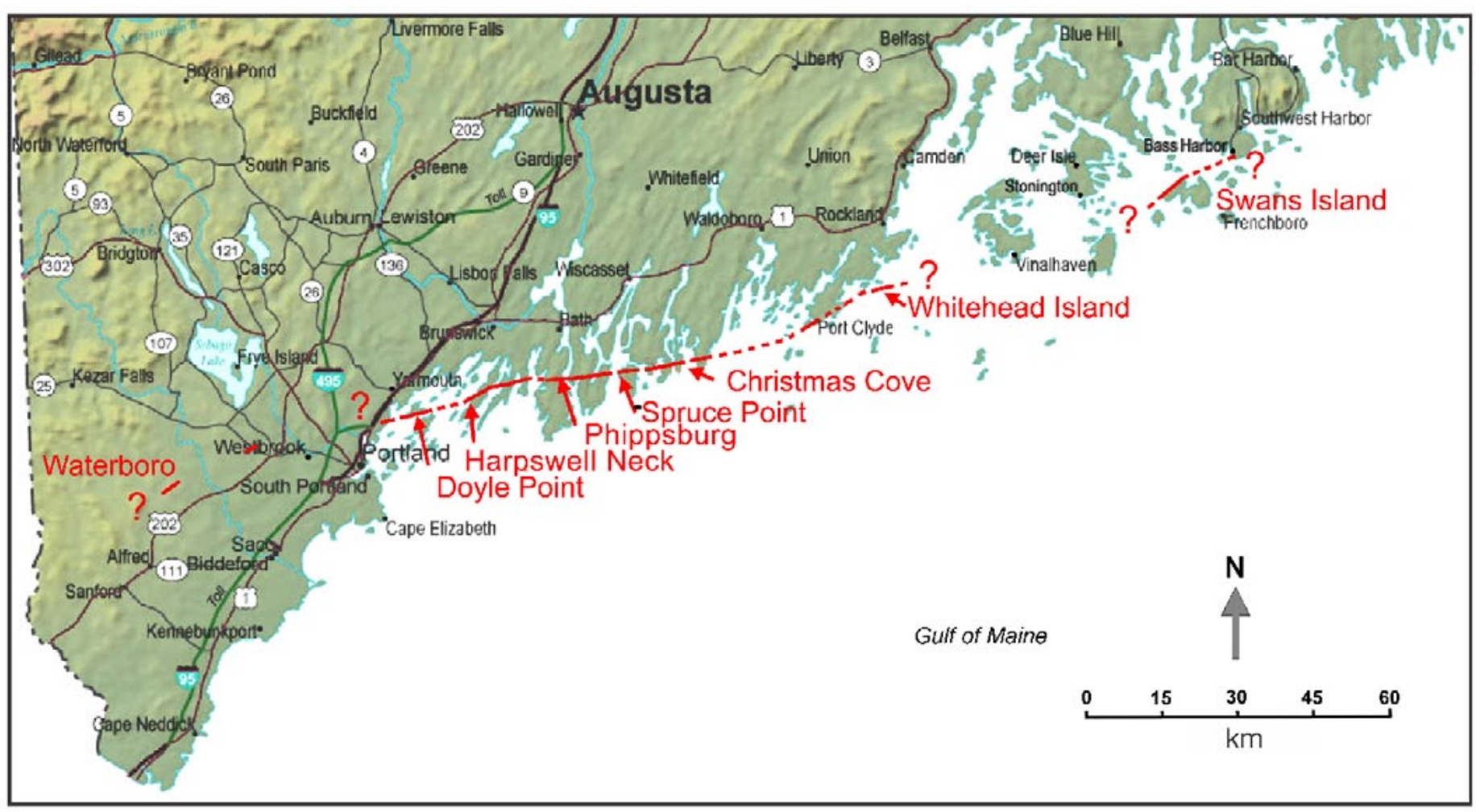

Figure 1. Location map of the Christmas Cove Dyke (red line segments) in southern coastal Maine (USA), based on 15 exposures between Waterboro and Swans Island. Some localities mentioned in the text are labeled. The dyke is extrapolated (short dashes) between shoreline exposures. Question marks indicate where the dyke trends into unexposed areas. Topographic map source: http://www.visitmaine.com/resource/visitmaine/pdf/Topographic.pdf

\section{FIELD OBSERVATIONS}

Field observations at 13 locations of the Christmas Cove Dyke are summarized in Table 1 . The dyke is recognized by its massive but jointed appearance with rusty to grey weathered surfaces and uniform darker fresh surfaces, not greenish or slightly foliated as are many older dykes in Maine. At 13 to $35 \mathrm{~m}$ wide, it is much larger than most of the basaltic dykes that are common in southern Maine, some of which represent other post-metamorphic igneous provinces and events as summarized by McHone (1992) and McHone and Sundeen (1995). In addition, the Christmas Cove Dyke commonly exhibits large polygonal cooling columns $0.4-1.0$ $\mathrm{m}$ in diameter and perpendicular to the dyke walls (Fig. 3). Joints parallel and perpendicular to the walls are common, and at some locations they promote erosion and useful interior exposures.

In general, the dyke is as durable as the surrounding metamorphic and plutonic rocks, so that it does not form large ridges or troughs from differential erosion except very locally. Outcrops are mainly coincidental with the removal of surficial cover by coastal wave erosion or road construction. A few inland hillside exposures, as at Phippsburg, are apparently due to glacial erosion. Probably the dyke exists between most outcrops under the sea or surficial materials, and it might be tracked by a suitable aeromagnetic survey as indicated by its sharp magnetic anomaly with a hand-held magnetometer. A few gaps along the dyke are due to offsets by faulting, en-echelon segments, or pinch-out structures. In most cases, the general strike of each exposed section of the dyke trends toward the next outcrop along the coast.

Areas where the dyke deviates significantly from its circa-075 general trend are found at its western and eastern locations, and from Harpswell Neck to Phippsburg (Table 1 and Fig. 1). At its westernmost outcrop in Waterboro, the dyke appears to trend to the southwest and toward the Onway Dyke exposures in southeast New Hampshire (Sundeen and Huff 1992). At its exposure on Swans Island, the dyke has turned more northeasterly toward the southern part of Mt. Desert Island (a possibly location is reported near Bass Harbor Light), but it has not been identified on current bedrock maps in Maine from Mt. Desert Island to Eastport, where we suspect it might continue as the Lepreau River Dyke (Fig. 2; S. Barr personal communication, 2013). Large gaps in mapped dyke locations are in areas of poor outcrop between Cumberland Foreside and Waterboro, Maine, and 


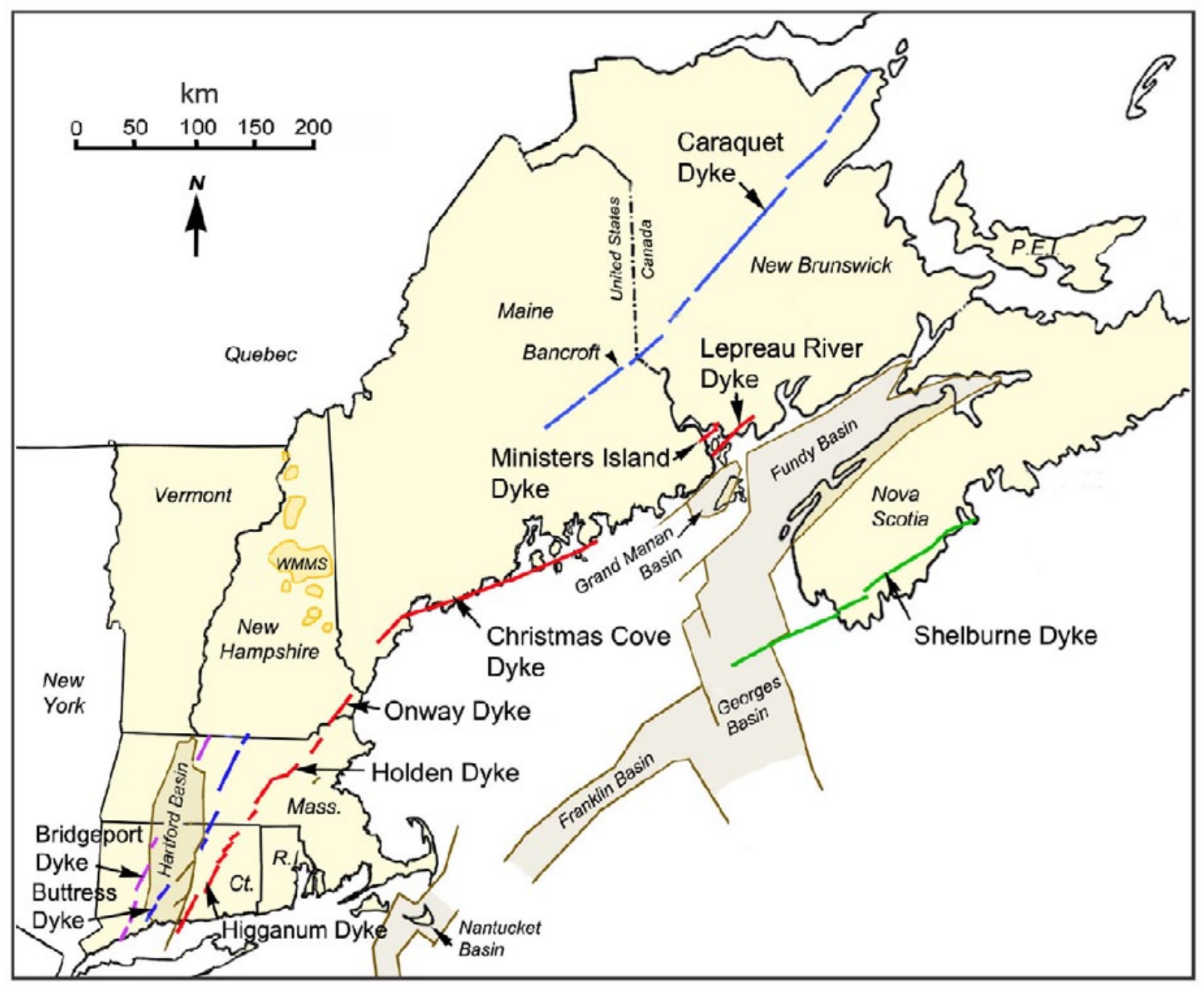

Figure 2. Generalized locations of large regional tholeiite dykes and Early Mesozoic basins that contain or may contain basalts, in New England states (USA) and Maritime Provinces (Canada). Coeval granitoid plutons are located in the White Mountain Magma series (WMMS) of New Hampshire. Offshore basin locations are located by Hutchinson et al. 1988.

from Waterboro into New Hampshire. The dyke also trends into a mostly water-covered area toward the southern part of Vinalhaven and through the island archipelago south of Stonington, but without reports of its occurrence (Fig. 1).

The dyke and potential extensions into southern New England and New Brunswick cross faults and structures within Ganderian crustal belts southeast of the Norumbega fault zone (West et al. 2008). The dyke intrudes rocks of the Ellsworth, Mascarene, and St. Croix terranes in Maine (Merrimack and coastal lithotectonic blocks of Osberg et al. 1985), as well as through Silurian to Devonian granitic plutons. In the Casco Bay area the dyke crosses the Flying Point Fault with no apparent offset, although the fault had approximately $4 \mathrm{~km}$ of west-side-up displacement in post-Paleozoic time (West et al.1993). Because the dyke intruded without regard to major upper crustal structures, its path may have initiated in the lower lithosphere along a pre-existing zone of weakness and then propagated both vertically and laterally through the brittle upper crust in a direction consistent with the regional stress field (McHone 1988).

In detail, however, it is clear that small faults and intrusional offsets in boundaries along the dyke are common at the current level of exposure. Sharp steps and offsets of the dyke of a few centimetres to several metres are present at Doyle Point, Harpswell Neck, Phippsburg, and Whitehead Island (Fig. 3). The steps follow high-angle metamorphic and plutonic foliations as well as brittle fractures. In nearly all cases the offsets are in a left-lateral sense along strike. This is the same offset direction shown by en-echelon steps of the Higganum Dyke in Connecticut (Rodgers 1985), which as discussed later is probably part of the same dyke system. Presumably, extensional stress at this level was not quite normal to many dyke segments but was slightly more to the NW-SE, so that the overall direction of the dyke path is a little more NE-SW than individual segments (McHone 
Table 1. Field observations of the Christmas Cove Dyke, SW to NE.

\begin{tabular}{|c|c|c|c|c|c|}
\hline Location & $\begin{array}{l}\text { General } \\
\text { Strike }\end{array}$ & $\begin{array}{l}\text { Contact } \\
\text { Azimuth }\end{array}$ & Dip & $\begin{array}{l}\text { Width } \\
(\mathrm{m})\end{array}$ & Notes \\
\hline $\begin{array}{l}\text { Rte } 202 / 4 \text {, } \\
\text { Waterboro }\end{array}$ & N50E & $50 ?$ & $90 ?$ & $>8$ & $\begin{array}{l}\text { partially exposed road cut on the } \\
\text { south side }\end{array}$ \\
\hline $\begin{array}{l}\text { shore at Cumber- } \\
\text { land Foreside }\end{array}$ & $\mathrm{N} 80 \mathrm{E}$ & 80 & $85 \mathrm{~S}$ & 18 & $\begin{array}{l}\text { well exposed in a low hill, contact } \\
\text { rotates at the north end }\end{array}$ \\
\hline $\begin{array}{l}\text { Doyle Point, } \\
\text { Yarmouth }\end{array}$ & N78E & 73 & $68 \mathrm{~N}$ & 32.3 & $\begin{array}{l}\text { well exposed, trends toward } \\
\text { Harpswell Neck }\end{array}$ \\
\hline $\begin{array}{l}\text { tank farm, Harpswell } \\
\text { Neck }\end{array}$ & $\mathrm{N} 71 \mathrm{E}$ & 79 & $60 \mathrm{NW}$ & 19 & $\begin{array}{l}\text { partially offset (faulted?) to the } \\
\text { north, with slickensides }\end{array}$ \\
\hline Rte. 123, Harpswell & N53E & 80 & 90 & $>20$ & $\begin{array}{l}\text { in a low cut on the SE roadside, } \\
\text { contacts not well exposed }\end{array}$ \\
\hline $\begin{array}{l}\text { Mountain Rd, } \\
\text { Harpswell }\end{array}$ & N83E & $91 ?$ & $55 \mathrm{~S}$ & $>20$ & $\begin{array}{l}\text { contacts not well exposed; very } \\
\text { large columns dipping S }\end{array}$ \\
\hline $\begin{array}{l}\text { Dingley Rd, } \\
\text { Harpswell }\end{array}$ & $90 \mathrm{E}$ & $\begin{array}{l}\text { varies } 62- \\
\quad 80\end{array}$ & $84 \mathrm{~S}$ & 19.2 & $\begin{array}{l}\text { low road cut, } \mathrm{N} \text { and } \mathrm{S} \text { contacts } \\
\text { poorly exposed }\end{array}$ \\
\hline $\begin{array}{l}\text { hillside above store, } \\
\text { Phippsburg }\end{array}$ & $\mathrm{N} 84 \mathrm{E}$ & 89 & $81 \mathrm{~S}$ & 28.4 & $\begin{array}{l}\text { in wooded bank above store; jog in } \\
\text { woods is } \mathrm{N} 30 \mathrm{E}\end{array}$ \\
\hline $\begin{array}{l}\text { Spruce Point, } \\
\text { Boothbay Harbor }\end{array}$ & N83E & 78 & $85 \mathrm{~N}$ & 12 & $\begin{array}{l}\text { attitude from fractures, with the } \\
\text { center exposed in whalebacks }\end{array}$ \\
\hline $\begin{array}{l}\text { Christmas Cove, } \\
\text { South Bristol }\end{array}$ & N77E & 77 & $85 \mathrm{~S}$ & 22 & $\begin{array}{l}\text { interior open along small cove, } \mathrm{N} \\
\text { contact exposed }\end{array}$ \\
\hline $\begin{array}{l}\text { Whitehead Island, } \\
\text { St. George }\end{array}$ & N75E & $\begin{array}{l}\text { varies } 10- \\
90\end{array}$ & 90 & 13 & $\begin{array}{l}\text { visible with Google Earth on the S } \\
\text { shoreline; several left-lateral jogs }\end{array}$ \\
\hline $\begin{array}{l}\text { SW shoreline, Swans } \\
\text { Island }\end{array}$ & N55E & 55 & $85 \mathrm{~S}$ & 35 & $\begin{array}{l}\text { exposed along the SW coastline and } \\
\text { on the northern shore }\end{array}$ \\
\hline
\end{tabular}

1988).

The Caraquet Dyke is exposed on the northwest side of the Mattawamkeag River at the western town line of Bancroft, off Pitloc Road about $4 \mathrm{~km}$ from Rte. 171 in Maine. The dyke is at least $15 \mathrm{~m}$ wide, strikes 074 , and dips nearly vertically (only the northern side is exposed). A leftlateral fault in the northern contact has an offset of $1.2 \mathrm{~m}$. Fresh surfaces are dark grey, fine-grained, dense, hard, and unaltered.

In summary, Christmas Cove Dyke exposures are generally excellent but intermittent. Field characteristics include its large size, prominent columns, lack of alteration, and continuity along its trend. As we discuss, the observed length of $190 \mathrm{~km}$ in Maine is only part of a much longer dyke system between southern New England, USA, and southern New Brunswick, Canada.

\section{PETROGRAPHY}

Petrographic thin sections are dominated by anhedral Ca-rich augite and subhedral to euhedral calcic plagioclase laths in a subophitic texture (Fig. 4). Grain sizes vary from a few tenths $\mathrm{mm}$ to $2 \mathrm{~mm}$ or more from contacts toward centers (fine- to medium-grained). Both sulfides and iron oxides are common but have few crystal faces. Patches of fine-grained granophyric feldspar and quartz in central areas of the dyke usually show elongated needles of apatite. Felsic granophyres in the North Mountain Basalt are ascribed to liquid immiscibility by Kontak et al. (2002) and may have a similar origin in their feeder dykes, but we have not made particular studies or analyses of the material. Small brown-green, pleochroic grains are hornblendes with variable compositions, and a few small biotite grains appear around some augite rims, but in general the rock is fresh and unaltered.

The dyke is everywhere porphyritic with abundant 

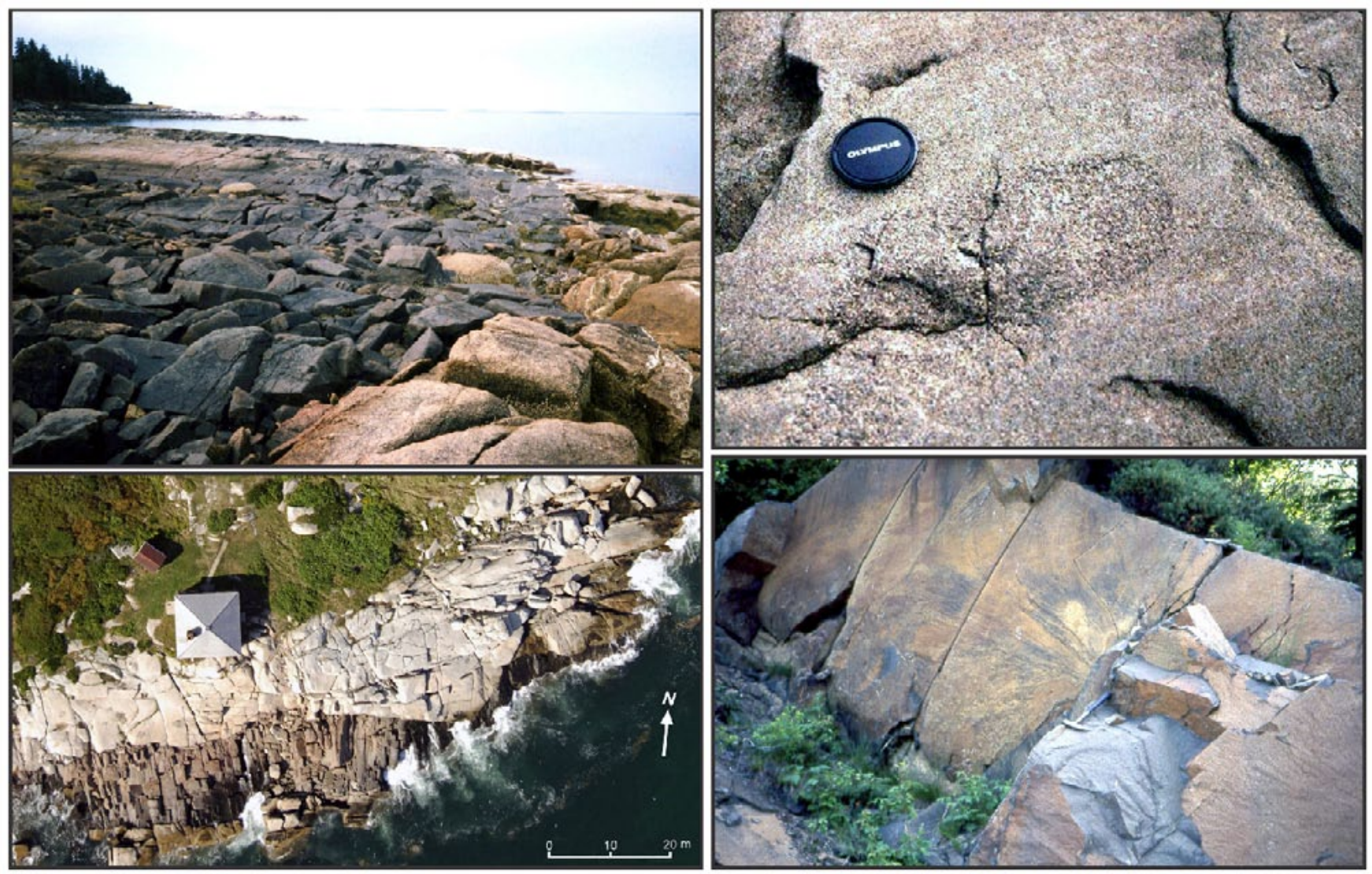

Figure 3. Field views of the Christmas Cove Dyke. Upper left: the dyke at Swans Island, looking SW along the NW contact, width about $30 \mathrm{~m}$ and dip near vertical. Dyke columns cross the view parallel to the near shoreline. Lower left: overhead aerial photo below the Whitehead Island Light, St. George, where the dyke has a width near $13 \mathrm{~m}$ and local trend variations around AZ 80. Note the 8-m jog to the north along a fracture near the eastern end of the outcrop (photo courtesy of Marinas.com). Upper Right: coarse dyke inclusion at Spruce Point (Boothbay Harbor). Lens cap diameter is $5 \mathrm{~cm}$. Lower Right: large columns at Mountain Road (Harpswell) are tilted to $30^{\circ} \mathrm{S}$, indicating a dyke dip of $60{ }^{\circ} \mathrm{N}$. Note rock hammer for scale.

euhedral to subhedral orthopyroxene crystals several $\mathrm{mm}$ or more in length (Figs. 4 and 5). The orthopyroxene commonly shows good crystal outlines but can be corroded, with interior holes or ragged edges, and rims of magnetite and/ or small grains of pigeonite. Clumps or clusters of mediumto coarse-grained augite are also common, typically with coarse plagioclase laths in a glomeroporphyritic texture. The clusters range from a few $\mathrm{mm}$ to many $\mathrm{cm}$ in size, and larger pieces can be visible on smooth surfaces of the dyke as well as filling thin sections (Fig. 5). Individual coarse grains of clinopyroxene and plagioclase in the dyke may be from these clusters, which are often partly disaggregated. At Spruce Point the clusters occur as streamlined inclusions up to $20 \mathrm{~cm}$ long and are visible on glacially smoothed surfaces (Fig. 3).

Thin sections of dyke contacts show microporphyritic crystals of plagioclase, augite, and orthopyroxene scattered in a dark glassy matrix (Fig. 5). The small clusters of coarse pyroxene and plagioclase are also found near contacts, including individual large rounded grains of augite. At Doyle Point the contact with granitic wall rock has a thin layer of brown melted silicic material, which is also streaming in thin bands into the dyke with its flow direction (Fig. 5). Contamination of the original dyke magma by wallrock melting and disaggregation may be locally significant, as reported for the Higganum Dyke by Philpotts and Asher (1993), although in a petrogenetic study of the similar Ministers Island Dyke, Dunn and Stringer (1990) calculated contamination as less than a few percent. Perry (1994) came to the same conclusion with the Swans Island dyke section. Despite visual evidence of granitic "wisps" along the margin of the dyke, contamination (at least at the exposed crustal level) was apparently quite limited. 

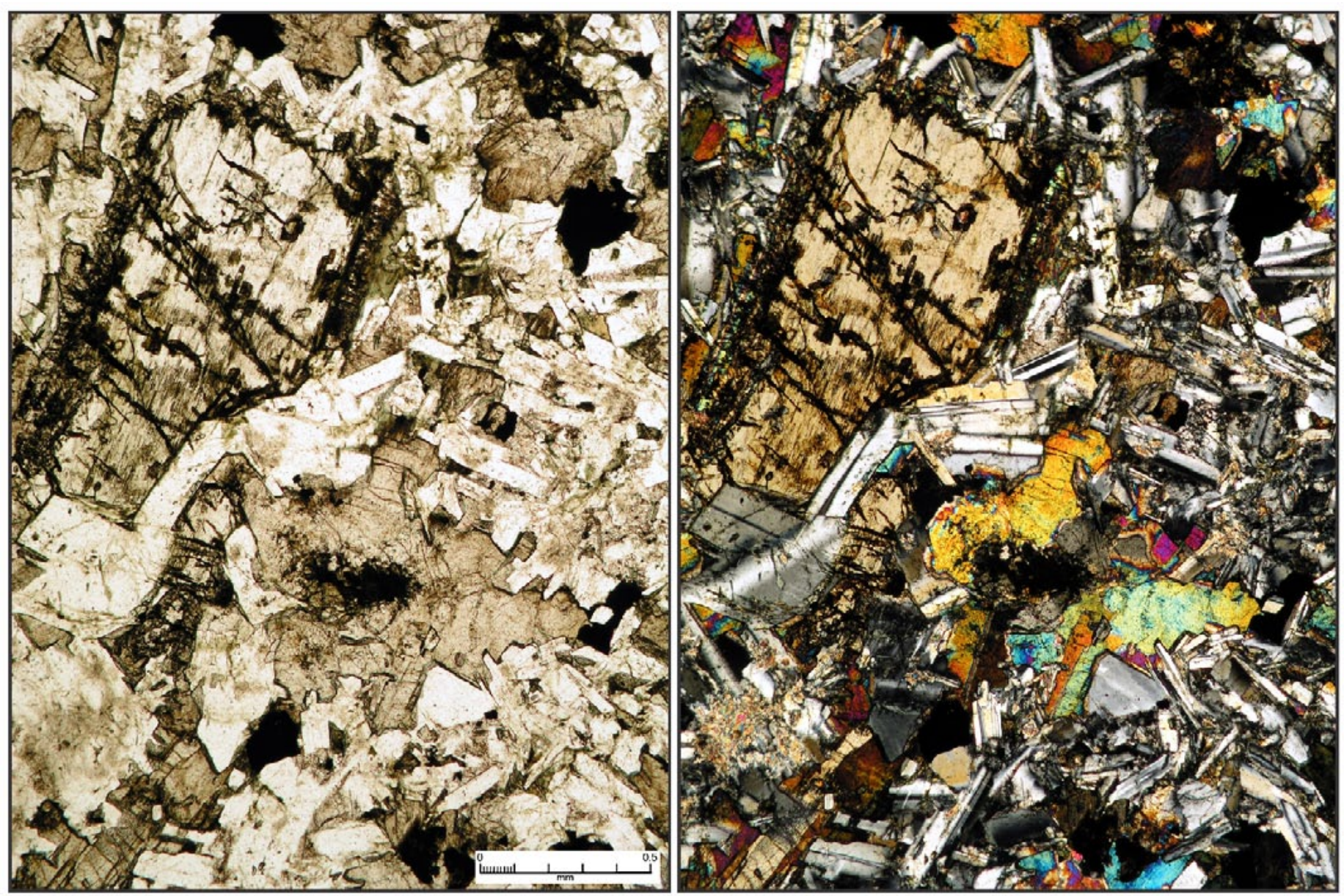

Figure 4. Photomicrographs of the Christmas Cove dyke at Mountain Road, Harpswell, at 50x total magnification (note the $0.5 \mathrm{~mm}$ scale bar.). Left side is in plane polarized light, right side is crossed polarized. Off-white laths are Ca-rich plagioclase, intermingled with subophitic pale brown augite. The large $(1.2 \mathrm{~mm}$ long $)$ corroded phenocryst of pale green orthopyroxene is partly rimmed by elongated grains of dark pigeonite.

\section{MINERAL CHEMISTRY}

We did not conduct a detailed investigation into mineral chemistry except for SEM/EDS analyses of some plagioclase and pyroxene phenocrysts in a sample of the dyke at Swans Island, which are presented in Appendix A. Figure 6 shows ternary plots of these compositions. Enstatite (var. bronzite $\left.\sim \mathrm{Wo}_{5} \mathrm{En}_{78} \mathrm{Fs}_{17}\right)$ and augite $\left(\sim \mathrm{Wo}_{35} \mathrm{En}_{54} \mathrm{Fs}_{11}\right)$ show little variation between cores and rims, with tightly grouped clusters. Plagioclase phenocrysts (bytownite or labradorite; $\mathrm{An}_{64-72}$ ) have rims that are both similar to, and more sodic than, the calcic cores, with some solid solution variation within the cluster. The Caraquet Dyke lacks orthopyroxene but may contain more pigeonite than the Christmas Cove Dyke and related tholeiites, as well as olivine in the matrix (Greenough and Papezik 1986). Fields for pyroxenes from the Caraquet and Shelburne dykes are included in Figure 6 for comparison. Pigeonite (but no olivine) exists in the Christmas Cove Dyke as well, but it was not analyzed in this study.

\section{PETROCHEMISTRY}

We selected 19 samples for whole-rock chemical analyses (Tables 2 and 3), including single samples from related dykes in Connecticut and New Hampshire, seven samples along the Christmas Cove Dyke in Maine, a sample from the Caraquet Dyke at Bancroft, Maine, and nine samples roughly evenly spaced across the dyke at its excellent shoreline exposure on Swans Island. The single samples were fresh-appearing pieces broken from the interior or about a third of the width into the dyke from a contact (where one was visible). Most samples were analyzed by wavelength dispersive X-ray fluorescence spectrometry at Hamilton College and the University of Connecticut. Rock samples were cleaned, crushed, and pulverized in a tungsten carbide ring mill. The rock powders were ignited, and then fluxed with Li-tetraborate and fused into glass disks. Analyses were run against calibration curves defined using 12 USGS standards, 10 international standards, and 10 in-house standards. Precision and accuracy of the analyses were 

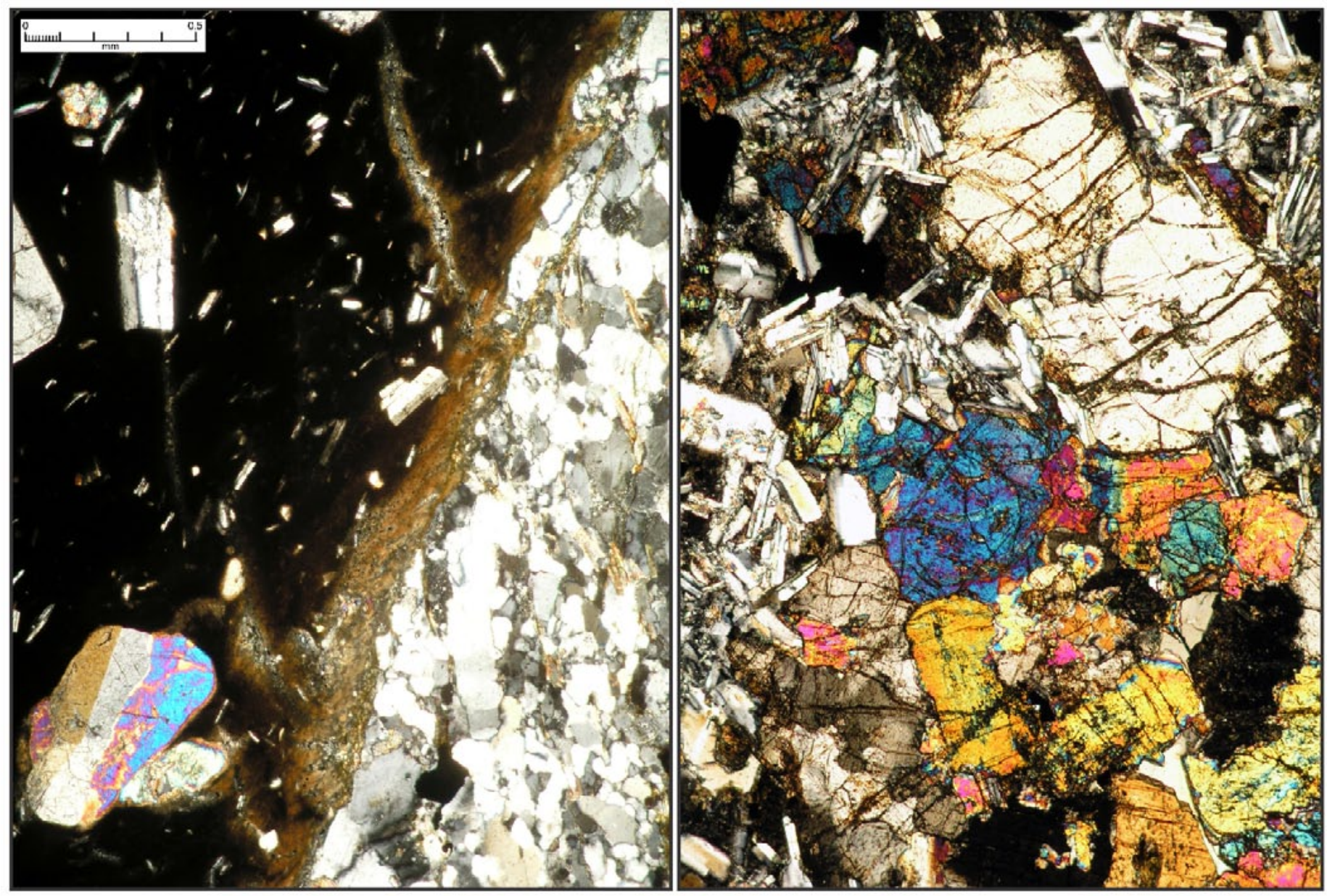

Figure 5. Micro-structures at Doyle Point, Cumberland Foreside, at 50x total magnification (note the $0.5 \mathrm{~mm}$ scale bar.). Both images use cross polarized light. Left: contact with quartz monzonite, with phenocrysts of angular plagioclase and rounded augite (twinned) in a glassy matrix. Wisps of silicic material are streaming from a brown melt layer at the contact, in the flow direction of the dyke. Right: $1.6 \mathrm{~mm}$ long phenocryst of orthopyroxene (enstatite, formerly called bronzite) rests against a medium-grained glomerophyric cluster or auto-brecciated augite.

estimated by comparing the results of multiple analyses of USGS standard G-2 run as an unknown during the analytical period to published accepted values for this standard. Trace element samples in Table 2 that include rare earth elements are analyzed by ICP by Activation Laboratories Ltd.

The whole-rock chemical analyses are presented in Table 2. Only very minor differences are evident among the compositions of dyke samples from Hurd State Park (Connecticut) through New Hampshire to Swans Island (Maine). The dyke system is remarkably uniform both petrographically and chemically along its great length, with small variations possibly related to fractionation of orthopyroxene phenocrysts as well as minor assimilation of wall rocks, as also observed by Dorais et al. (2005) at Onway, and Dunn and Stringer (1990) at Ministers Island.

The complete Swans Island exposure allowed us to analyze a series of samples across the dyke, roughly evenly spaced, to search for possible compositional differences from flow fractionation or multiple magma intrusions (Table 3). Across the dyke, chemical differences are small and nonsystematic except for slightly higher $\mathrm{MgO}$ and lower $\mathrm{TiO}_{2}$ concentrations in the interior of the dyke relative to the outer margins. The small compositional differences can largely be explained (and numerically modelled) by slight variations in phenocryst populations; relatively large variations in concentrations in some of the LIL elements (e.g., Rb, Ba, and $\mathrm{Sr}$ ) seen in some samples are apparently due to alteration and weathering (Table 3, analysis 1h). Overall, the Swans Island dyke is remarkably uniform in composition considering it is $35 \mathrm{~m}$ wide and was carrying a fairly high phenocryst load. Flowage differentiation and in-situ differentiation played only minor roles in modifying bulk rock compositions, probably in part due to the turbulent flow of this large dyke that kept it mixed and relatively uniform in composition. 

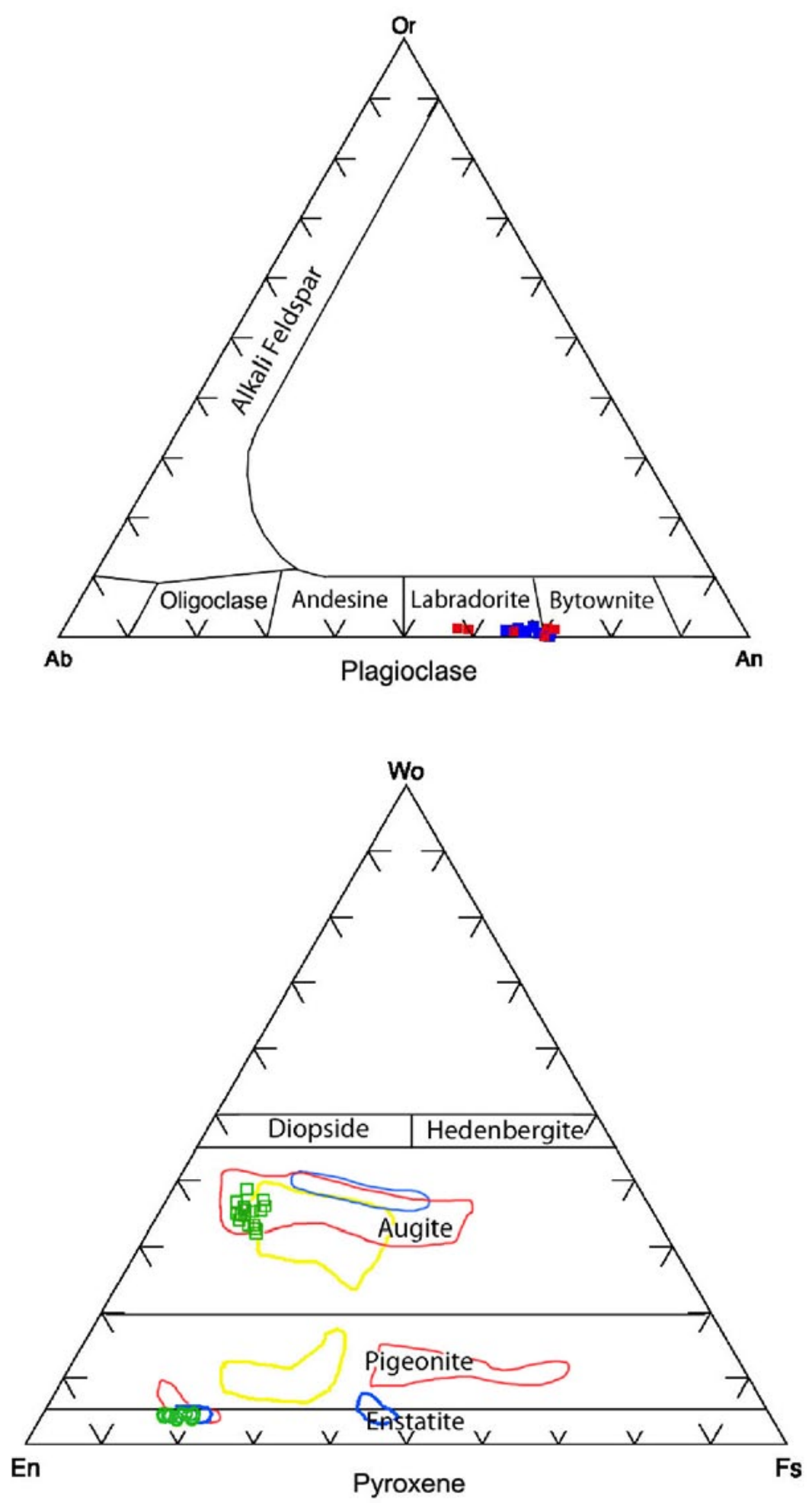

Figure 6. Ternary classification plots of pyroxene and plagioclase phenocryst compositions from the dyke at Swans Island (Appendix A). On the orthoclase-albite-anorthite diagram, labradorite/bytownite cores are shown in solid blue squares, with rims in solid red. On the wollastonite-enstatite-ferrosilite diagram, augite analyses are empty green squares and enstatite (var. bronzite) are empty green circles. For comparison are fields of augite, enstatite, and pigeonite from the Onway and Higganum dykes (Dorais et al. 2005) outlined in red; the Caraquet Dyke (Greenough and Papezik 1986) outlined in yellow, and the Shelburne Dyke (Papezik and Barr 1981; Dostal and Durning 1998) outlined in blue. 
Plots of the chemical analyses show the minor fractionation of the dyke magma both along its length and across its width (Fig. 7). The dyke has a tholeiitic composition with only slight variation in $\mathrm{MgO} / \mathrm{FeO}_{\text {total }}$ ratios and alkali enrichment (Irvine and Baragar 1971), which is probably related to removal or addition of Mg-rich pyroxene and plagioclase phenocrysts and glomerophyric clumps (Figs. 4 and 5). Compositions are generally in the basaltic andesite field of LeBas et al. (1986) but overlap into true basalt, as is common for quartz tholeiite derived from sub-continental lithospheric mantle (Dorais et al. 2005). Rare earth elements normalized to chondrite (Sun and McDonough 1989) have relatively flat patterns with $(\mathrm{La} / \mathrm{Lu})_{\mathrm{N}}$ ratios about 3.0 to 7.5 (Fig. 7b). Although the ratio lines for analyses from the Christmas Cove, Onway, and Hurd Park dykes are the same within analytical error, they are distinct from REE patterns
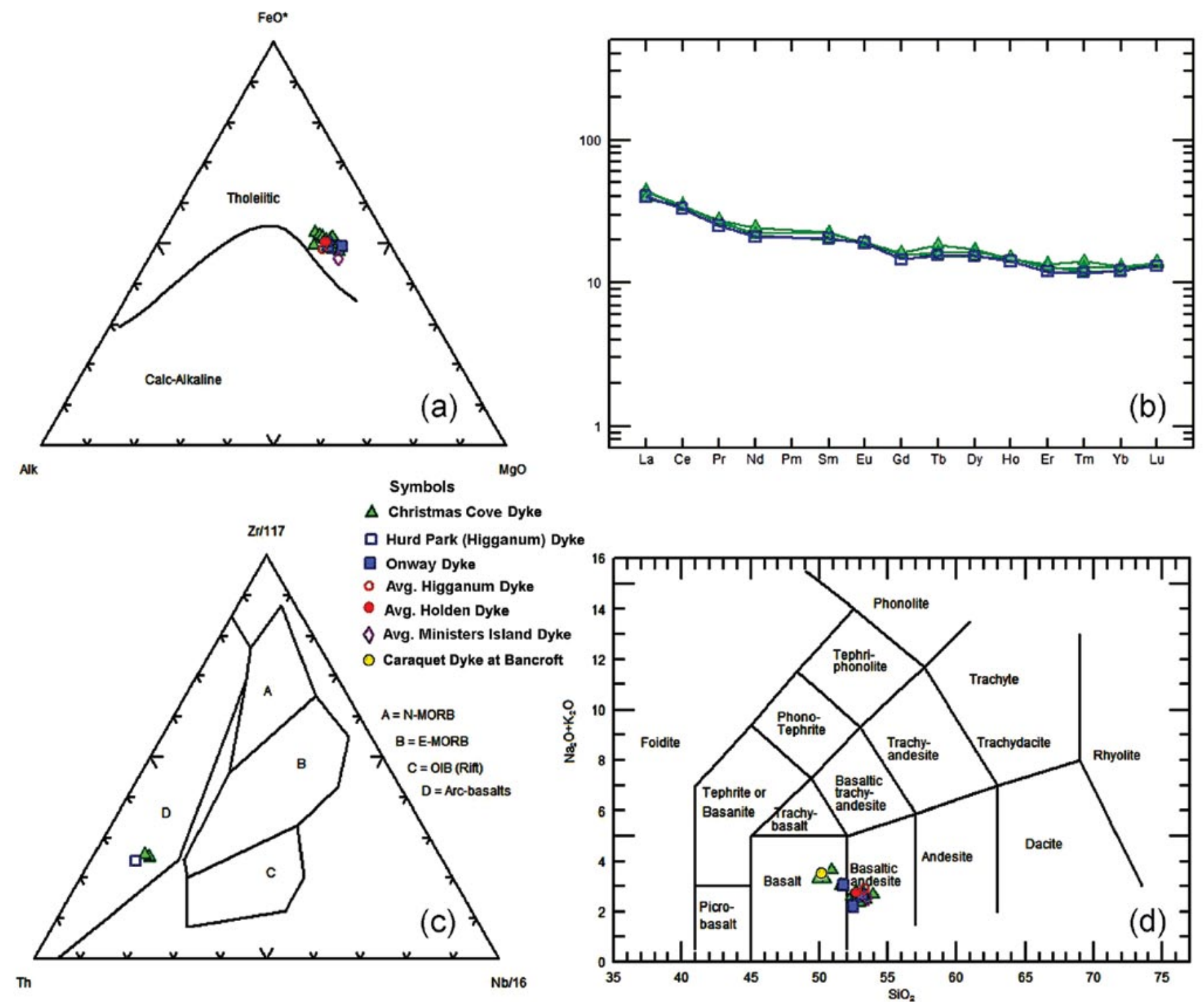

Figure 7. Geochemical diagrams of the Christmas Cove Dyke and regional dykes. See the symbol table for dyke labels. Diagrams: (a) Alkalies-Iron-Magnesium classification and differentiation diagram after Irvine and Baragar 1971. (b) Rare earth elements normalized against chondrite values after Sun and McDonough, 1989. (c) Source affinity classification after Wood 1980. (d) Silica-Alkalies volcanic classification after LeBas et al. (1986). Diagrams b and c have one analysis each of the Christmas Cove, Onway, and Higganum dykes. Average analyses are from Philpotts and Martello (1986) and Dunn and Stringer (1990). The diagrams were produced using Igpet 2011 by Terra Softa Inc. 
Table 2. Chemical analyses of the Christmas Cove Dyke and related dykes.

\begin{tabular}{|c|c|c|c|c|c|c|c|c|c|c|c|c|c|}
\hline Sample & HPK & RT-4 & CF-1 & DP-1 & DP-2 & MTR & SP-1 & $\mathrm{XC}-2$ & $\mathrm{XC}-1$ & SI av & BAN & CAR & BUT \\
\hline $\mathrm{SiO}_{2}$ (wt. \%) & 52.10 & 51.11 & 50.30 & 50.40 & 49.75 & 51.60 & 50.88 & 51.70 & 49.21 & 52.03 & 50.00 & 51.12 & 51.74 \\
\hline $\mathrm{TiO}_{2}$ & 0.98 & 1.11 & 1.16 & 1.15 & 1.27 & 1.11 & 1.13 & 1.10 & 1.18 & 1.12 & 0.79 & 0.83 & 0.79 \\
\hline $\mathrm{Al}_{2} \mathrm{O}_{3}$ & 15.00 & 12.37 & 13.94 & 14.30 & 13.82 & 14.10 & 13.92 & 13.90 & 13.59 & 14.05 & 14.54 & 14.78 & 15.12 \\
\hline $\mathrm{Fe}_{2} \mathrm{O}_{3}$ & 10.80 & 12.12 & 11.90 & 11.20 & 12.70 & 11.50 & 11.70 & 11.60 & 13.09 & 11.03 & 12.66 & 12.18 & 10.63 \\
\hline $\mathrm{MnO}$ & 0.17 & 0.17 & 0.17 & 0.19 & 0.20 & 0.17 & 0.18 & 0.17 & 0.17 & 0.16 & 0.20 & 0.19 & 0.19 \\
\hline $\mathrm{MgO}$ & 7.64 & 8.24 & 7.31 & 7.23 & 7.05 & 7.59 & 7.51 & 8.01 & 7.64 & 7.44 & 7.19 & 7.58 & 7.40 \\
\hline $\mathrm{CaO}$ & 10.60 & 11.86 & 11.63 & 10.40 & 11.98 & 10.30 & 11.13 & 10.20 & 11.87 & 10.62 & 11.14 & 10.34 & 11.11 \\
\hline $\mathrm{Na}_{2} \mathrm{O}$ & 2.04 & 2.26 & 2.87 & 1.94 & 2.46 & 1.92 & 2.25 & 1.94 & 2.53 & 2.06 & 2.69 & 2.05 & 2.43 \\
\hline $\mathrm{K}_{2} \mathrm{O}$ & 0.50 & 0.75 & 0.72 & 0.54 & 0.75 & 0.60 & 0.64 & 0.61 & 0.70 & 0.50 & 0.60 & 0.58 & 0.44 \\
\hline $\mathrm{P}_{2} \mathrm{O}_{5}$ & 0.12 & 0.00 & & 0.13 & & 0.13 & 0.10 & 0.13 & & 0.13 & 0.18 & 0.12 & 0.15 \\
\hline LOI & 0.20 & & & 2.25 & & 0.65 & 1.03 & 0.95 & & 0.75 & & & \\
\hline Total & 100.15 & 99.99 & 100.00 & 99.73 & 99.98 & 99.67 & 100.47 & 100.31 & 99.98 & 99.89 & 99.99 & 99.76 & 100.00 \\
\hline $\mathrm{Rb}(\mathrm{ppm})$ & 17 & 30 & 23 & 10 & 24 & 27 & 22 & 10 & 24 & 25 & 16 & 17 & 12 \\
\hline $\mathrm{Sr}$ & 181 & 164 & 199 & 166 & 231 & 187 & 175 & 162 & 172 & 205 & 158 & 134 & 111 \\
\hline Y & 22.1 & 25.3 & 17.0 & 16.0 & 19.0 & 23.3 & 23.0 & 16.0 & 22.9 & 31.0 & 18.0 & 25.0 & 29.0 \\
\hline $\mathrm{Zr}$ & 74 & 102 & 114 & 100 & 126 & 83 & 81 & 101 & 86 & 98 & 78 & 65 & 66 \\
\hline $\mathrm{Nb}$ & 4.1 & 6.3 & 10.0 & 10.0 & 9.0 & 5.6 & 5.4 & 10.0 & 5.0 & & 8.0 & 5.0 & \\
\hline $\mathrm{Ba}$ & 140 & 201 & 192 & 148 & 204 & 158 & 143 & 141 & 185 & 178 & 170 & 124 & \\
\hline $\mathrm{Cr}$ & 241 & 231 & 230 & 300 & 298 & 329 & 328 & 300 & 299 & 291 & 112 & 141 & 202 \\
\hline $\mathrm{Ni}$ & 92 & 83 & 75 & & 83 & 111 & 113 & & 92 & 79 & 46 & 53 & 51 \\
\hline V & 233 & 268 & 223 & & 246 & 273 & 258 & & 246 & 281 & 192 & 254 & 291 \\
\hline Co & 41 & 47 & 55 & & 53 & 49 & 48 & & 43 & & 48 & & \\
\hline $\mathrm{Cu}$ & 107 & 122 & 135 & & 138 & 108 & 112 & & 109 & & 88 & 65 & 104 \\
\hline $\mathrm{Zn}$ & 82 & 93 & 59 & & 89 & 63 & 85 & & 82 & 85 & 72 & 75 & \\
\hline Cs & 1.4 & 1.4 & & & & 1.5 & 0.7 & & 0.7 & & & & \\
\hline $\mathrm{La}$ & 9.55 & 11.2 & & & & 10.4 & 10.2 & & 9.24 & & & & \\
\hline $\mathrm{Ce}$ & 20.4 & 24.9 & & & & 20.6 & 21.5 & & 20.9 & & & & \\
\hline $\operatorname{Pr}$ & 2.40 & 3.15 & & & & 2.62 & 2.52 & & 2.62 & & & & \\
\hline $\mathrm{Nd}$ & 9.79 & 11.90 & & & & 11.40 & 10.40 & & 9.99 & & & & \\
\hline Sm & 3.11 & 3.45 & & & & 3.45 & 3.38 & & 3.05 & & & & \\
\hline $\mathrm{Eu}$ & 1.10 & 1.24 & & & & 1.08 & 1.11 & & 1.12 & & & & \\
\hline Gd & 3.00 & 3.95 & & & & 3.33 & 3.22 & & 3.30 & & & & \\
\hline $\mathrm{Tb}$ & 0.58 & 0.67 & & & & 0.69 & 0.61 & & 0.58 & & & & \\
\hline Dy & 3.90 & 4.31 & & & & 4.34 & 4.20 & & 3.88 & & & & \\
\hline Ho & 0.80 & 0.96 & & & & 0.83 & 0.84 & & 0.85 & & & & \\
\hline Er & 1.98 & 2.45 & & & & 2.23 & 2.07 & & 2.16 & & & & \\
\hline $\mathrm{Tm}$ & 0.30 & 0.34 & & & & 0.36 & 0.32 & & 0.30 & & & & \\
\hline $\mathrm{Yb}$ & 2.06 & 2.20 & & & & 2.22 & 2.17 & & 2.04 & & & & \\
\hline $\mathrm{Lu}$ & 0.33 & 0.38 & & & & 0.34 & 0.34 & & 0.35 & & & & \\
\hline $\mathrm{Hf}$ & 2.0 & 2.7 & & & & 2.4 & 2.2 & & 2.4 & & & & \\
\hline $\mathrm{Ta}$ & 0.41 & 0.55 & & & & 0.56 & 0.55 & & 0.43 & & & & \\
\hline W & & 42.8 & & & & 53.4 & 71.4 & & & & & & \\
\hline $\mathrm{Tl}$ & 0.09 & 0.16 & & & & 0.15 & 0.14 & & 0.14 & & & & \\
\hline Th & 1.73 & 2.15 & & & & 1.78 & 1.72 & & 1.80 & & & & \\
\hline $\mathrm{U}$ & 0.36 & 0.45 & & & & 0.40 & 0.37 & & 0.37 & & & & \\
\hline
\end{tabular}

Sample codes: HPK = Higganum Dyke at Hurd State Park, Connecticut; RT-4 = Onway Dyke at its Route 4 roadcut west of Durham, New Hampshire; CF-1 = Christmas Cove Dyke at Cumberland Foreside, Maine; DP-1 and DP2 = Doyle Point on Cousins Island, Maine; MTR = Mountain Road in Harpswell, Maine; SP-1 = Spruce Point in Southport, Maine; XC-1 and XC-2 = Christmas Cove in South Bristol, Maine; SI average = average of 9 samples from Swans Island, Maine (Table 3); BAN = Caraquet Dyke at Mattawamkeag River in Bancroft, Maine; CAR = average of Caraquet Dyke analyses (Greenough and Papzeik 1986); BUT = average of Buttress Dyke analyses (Philpotts and Martello 1986). 
Table 3. Whole rock analyses across the dyke at Swans Island.

\begin{tabular}{|c|c|c|c|c|c|c|c|c|c|}
\hline Sample & SI-DB18 & SI-PP-1a & SI-PP-1b & SI-PP-1c & SI-PP-1d & SI-PP-1e & SI-PP-1f & SI-PP-1g & SI-PP-1h \\
\hline $\mathrm{SiO}_{2}$ (wt. \%) & 52.31 & 51.81 & 52.25 & 51.87 & 51.95 & 51.80 & 52.08 & 51.97 & 52.23 \\
\hline $\mathrm{TiO}_{2}$ & 1.09 & 1.15 & 1.17 & 1.11 & 1.01 & 1.07 & 1.06 & 1.16 & 1.23 \\
\hline $\mathrm{Al}_{2} \mathrm{O}_{3}$ & 13.61 & 14.64 & 13.70 & 13.66 & 13.97 & 14.28 & 13.91 & 14.07 & 14.64 \\
\hline $\mathrm{Fe}_{2} \mathrm{O}_{3}$ & 11.21 & 11.25 & 11.40 & 11.30 & 10.69 & 10.93 & 10.86 & 11.40 & 10.20 \\
\hline $\mathrm{MnO}$ & 0.17 & 0.16 & 0.17 & 0.17 & 0.16 & 0.16 & 0.16 & 0.17 & 0.16 \\
\hline $\mathrm{MgO}$ & 7.59 & 6.77 & 7.21 & 7.80 & 8.05 & 7.66 & 7.63 & 7.34 & 6.88 \\
\hline $\mathrm{CaO}$ & 10.64 & 10.83 & 10.58 & 10.74 & 10.89 & 10.69 & 10.70 & 10.74 & 9.77 \\
\hline $\mathrm{Na}_{2} \mathrm{O}$ & 1.85 & 2.18 & 2.12 & 2.06 & 1.99 & 2.21 & 2.12 & 1.94 & 2.06 \\
\hline $\mathrm{K}_{2} \mathrm{O}$ & 0.58 & 0.52 & 0.57 & 0.52 & 0.40 & 0.52 & 0.50 & 0.37 & 0.52 \\
\hline $\mathrm{P}_{2} \mathrm{O}_{5}$ & 0.13 & 0.13 & 0.13 & 0.13 & 0.11 & 0.12 & 0.12 & 0.13 & 0.16 \\
\hline LOI & 0.48 & 0.43 & 0.40 & 0.40 & 0.68 & 0.54 & 0.72 & 0.82 & 2.31 \\
\hline Total & 99.66 & 99.87 & 99.70 & 99.76 & 99.90 & 99.98 & 99.86 & 100.11 & 100.16 \\
\hline $\mathrm{Rb}(\mathrm{ppm})$ & 17 & 16 & 17 & 17 & 14 & 18 & 16 & 12 & 111 \\
\hline $\mathrm{Sr}$ & 168 & 195 & 176 & 179 & 200 & 194 & 190 & 185 & 360 \\
\hline $\mathrm{Y}$ & 23 & 36 & 33 & 30 & 26 & 24 & 34 & 38 & 37 \\
\hline $\mathrm{Zr}$ & 86 & 106 & 103 & 98 & 93 & 87 & 94 & 105 & 106 \\
\hline \multicolumn{10}{|l|}{$\mathrm{Nb}$} \\
\hline $\mathrm{Ba}$ & 146 & 168 & 153 & 137 & 116 & 140 & 137 & 131 & 476 \\
\hline $\mathrm{Cr}$ & 305 & 209 & 264 & 328 & 350 & 318 & 311 & 276 & 260 \\
\hline $\mathrm{Ni}$ & 84 & 74 & 78 & 85 & 93 & 78 & 91 & 76 & 48 \\
\hline $\mathrm{V}$ & 265 & 279 & 282 & 291 & 273 & 276 & 278 & 293 & 290 \\
\hline $\mathrm{Zn}$ & 80 & 87 & 86 & 80 & 79 & 76 & 81 & 91 & 107 \\
\hline Sc & 40 & 38 & 40 & 40 & 40 & 39 & 40 & 40 & 39 \\
\hline \multicolumn{10}{|c|}{ CIPW normative modes } \\
\hline$\% \mathrm{AN}$ & 62.02 & 59.39 & 57.91 & 58.89 & 61.05 & 58.10 & 58.62 & 62.14 & 61.19 \\
\hline Q & 5.82 & 4.47 & 5.10 & 4.14 & 4.45 & 3.46 & 4.49 & 5.70 & 7.38 \\
\hline Or & 3.53 & 3.15 & 3.46 & 3.15 & 2.42 & 3.14 & 3.03 & 2.25 & 3.20 \\
\hline $\mathrm{Ab}$ & 17.10 & 20.08 & 19.57 & 18.96 & 18.29 & 20.27 & 19.52 & 17.92 & 19.25 \\
\hline An & 27.92 & 29.38 & 26.92 & 27.15 & 28.67 & 28.10 & 27.66 & 29.42 & 30.36 \\
\hline Di & 20.44 & 19.91 & 20.94 & 21.27 & 20.72 & 20.22 & 20.79 & 19.63 & 15.21 \\
\hline Hy & 20.57 & 18.24 & 19.19 & 20.67 & 21.09 & 20.30 & 19.99 & 20.28 & 19.50 \\
\hline Wo & 0 & 0 & 0 & 0 & 0 & 0 & 0 & 0 & 0 \\
\hline $\mathrm{Ol}$ & 0 & 0 & 0 & 0 & 0 & 0 & 0 & 0 & 0 \\
\hline Ac & 0 & 0 & 0 & 0 & 0 & 0 & 0 & 0 & 0 \\
\hline Mt & 2.79 & 2.84 & 2.87 & 2.80 & 2.69 & 2.74 & 2.75 & 2.86 & 2.97 \\
\hline Il & 1.56 & 1.64 & 1.68 & 1.58 & 1.44 & 1.52 & 1.51 & 1.66 & 1.78 \\
\hline Hem & 0 & 0 & 0 & 0 & 0 & 0 & 0 & 0 & 0 \\
\hline $\mathrm{Ti}$ & 0 & 0 & 0 & 0 & 0 & 0 & 0 & 0 & 0 \\
\hline Ap & 0.28 & 0.28 & 0.28 & 0.28 & 0.24 & 0.26 & 0.26 & 0.28 & 0.35 \\
\hline
\end{tabular}

Notes: Samples are roughly equally spaced across the dyke, northwest to southeast. See the text for discussion of the analytical methods. 
for the Caraquet, Shelburne, and other dyke magmas (Dunn et al. 1998; Dostal and Durning 1998; Dorais et al. 2005).

Typical of most northern Central Atlantic Magmatic Province (CAMP) magmas, the dykes analyzed are all quartz tholeiites (Fig. 7a). In particular, the whole-rock chemical composition of the Christmas Cove Dyke is within the HTQ or "high-titanium quartz" normative tholeiite group of Weigand and Ragland (1970), who made a pioneering study of groups or magmatic types of Early Mesozoic dykes and basalts in eastern North America. This type is also found throughout most of the CAMP and it is thought to represent the oldest or initial magmatic event, now known to be mainly latest Triassic in age (Jourdan et al. 2009; Cirilli et al. 2009; Deenen et al. 2010). Two subsequent (Early Jurassic) types of quartz-normative tholeiites are labelled LTQ ("low titanium quartz") tholeiite, and HFQ ("high-iron quartz") tholeiite. The three types correspond to three dyke-to-basalt flow systems in southern New England that respectively are: Higganum-Holden Dyke to Talcott Basalt; Buttress-Ware Dyke to Holyoke Basalt; and Bridgeport-Pelham Dyke to Hampden Basalt (Fig. 8; Philpotts and Martello 1986).

The $\mathrm{MgO}$ vs. TiO2 diagram by Philpotts and Martello
(1986, their fig. 3) illustrates the petrogenetic connections among three source dykes and three basalts of the Hartford Basin in southern New England (Fig. 8). Co-genetic dyke and basalt compositions fall along particular linear trends that are mainly from pyroxene fractionation, as has been confirmed with additional analyses in later studies by Puffer (1992), McHone (1996), and Jourdan et al. (2009). In particular, Philpotts and Martello (1986) show that the Higganum dyke and the co-magmatic Fairhaven Dyke (separated by faulting) are the source for the Talcott Basalt, the earliest basalt of the basin. Superimposed on this diagram (Fig. 8), our dyke analyses show a good match of the Christmas Cove Dyke and the co-linear Onway Dyke with the Higganum/Fairhaven Dyke (including our sample from Hurd State Park). The Caraquet Dyke at Bancroft is also a match for the Buttress-Ware Dyke of southern New England, which is the source of the Holyoke Basalt.

In summary, whole-rock chemistry of the Christmas Cove dyke shows it to be essentially identical to the composition of the Ministers Island Dyke of New Brunswick, the Onway Dyke of New Hampshire and the HigganumHolden Dyke of Connecticut and Massachusetts. The

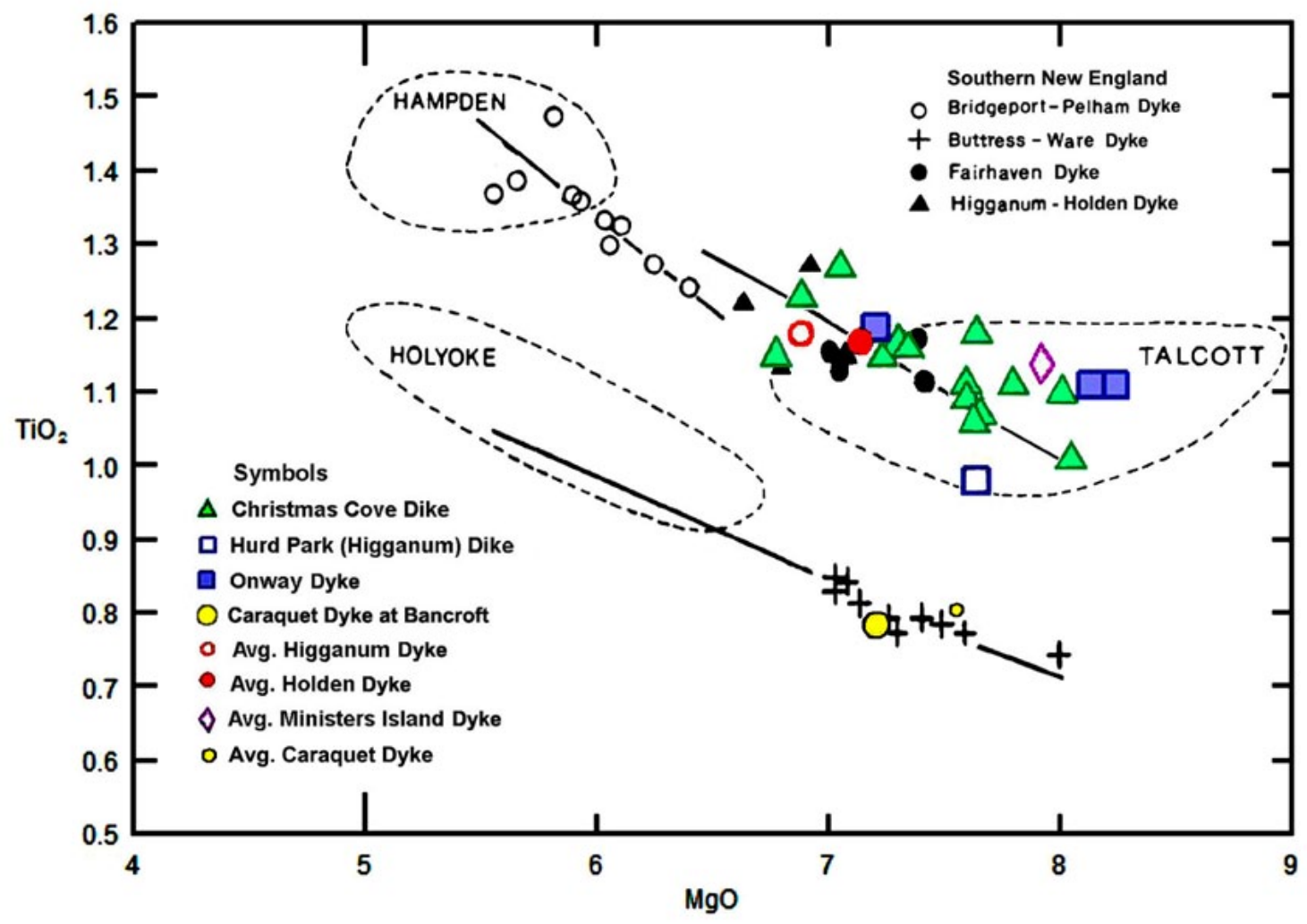

Figure 8. $\mathrm{TiO}_{2}$ vs $\mathrm{MgO}$ compositions of the Christmas Cove Dyke and related dykes, superimposed on the fractionation diagram of Philpotts and Martello (1986; fig. 3). Color symbols are also explained in Fig. 7, black symbols are explained on the figure. Talcott, Holyoke, and Hampden are flood basalts of the Hartford Basin (also see Puffer 1992). Black lines illustrate fractionation paths of basalts and their dyke sources. 
Caraquet Dyke including its locality at Bancroft has the same composition as the Buttress-Ware Dyke of southern New England. Their segments are geographically co-linear (with some wide gaps between exposures) and appear to share the same petrogenesis, and so both are considered to be co-magmatic intrusions. As will be discussed, separate dyke systems are derived from specific mantle sources with depths, temperatures, and enriched compositions that are distinct, producing magmas that vary from very similar to quite different across large areas of the CAMP (Tollo and Gottfried 1986; McHone 1996; Dorais et al. 2005).

\section{RADIOMETRIC AGES AND CORRELATIONS}

Previously published radiometric dates for regional dykes and basalts (Table 4) show a wide range of precision and accuracy using $\mathrm{K} / \mathrm{Ar}$ and ${ }^{40} \mathrm{Ar} /{ }^{39} \mathrm{Ar}$ methods. As presented by West and McHone (1997) and detailed herein, we have obtained additional whole-rock ${ }^{40} \mathrm{Ar} /{ }^{39} \mathrm{Ar}$ dates using samples of freshest-available dolerite from dyke exposures at Christmas Cove (South Bristol, Maine), Spruce Point (Boothbay Harbor), and Doyle Point (Yarmouth); the Caraquet Dyke on the NW side of the Mattawamkeag River near Bancroft, Maine; and the Higganum Dyke in a road cut in Hurd State Park near Haddam, Connecticut. Obviously weathered and altered areas in the samples were removed before crushing. ${ }^{40} \mathrm{Ar} /{ }^{39} \mathrm{Ar}$ radiometric analyses were performed on whole-rock samples of crushed splits at the radiometric laboratory at the University of Maine, following standard methods outlined in West et al. (1993).

The three samples from the Christmas Cove Dyke (DP-1, MR-1, SP-1), one sample from the Caraquet Dyke (Ban-1), and one sample from the Higganum Dyke (HPK1) were analyzed as whole rock samples using the ${ }^{40} \mathrm{Ar} /{ }^{39} \mathrm{Ar}$ incremental heating technique (7 heating steps in each sample). Analytical results of these experiments and the laboratory procedures employed are provided in Appendix B. Release spectra diagrams are shown in Figure 9, and results are discussed below.

\section{Caraquet Dyke}

A single sample of the Caraquet Dyke collected near Bancroft, Maine yielded an essentially concordant age spectrum with total gas (201.7 Ma), plateau (201.2 $\mathrm{Ma})$, and isotope correlation (201.8 Ma) ages all agreeing within analytical uncertainties. Release spectra (Fig. 9a) and isotope correlation (not shown) diagrams reveal no signs of excess ${ }^{40} \mathrm{Ar}$ contamination or ${ }^{40} \mathrm{Ar}$ loss. Based on these uncomplicated results, we interpret Caraquet dyke emplacement to have occurred at $201.5 \pm 2.4 \mathrm{Ma}$ (the average of the total gas, plateau, and isotope correlation ages).

Table 4. Radiometric dates (Ma) of regional dykes and basalts.

\begin{tabular}{|c|c|c|c|c|c|c|}
\hline Method & $\begin{array}{c}\mathrm{K} / \mathrm{Ar} \\
\text { whole rock }\end{array}$ & $\begin{array}{c}\mathrm{K} / \mathrm{Ar} \\
\text { plagioclase }\end{array}$ & $\begin{array}{c}{ }^{40} \mathrm{Ar} /{ }^{39} \mathrm{Ar} \\
\text { biotite }\end{array}$ & $\begin{array}{c}{ }^{40} \mathrm{Ar} /{ }^{39} \mathrm{Ar} \\
\text { whole rock }\end{array}$ & $\begin{array}{l}{ }^{40} \mathrm{Ar} /{ }^{39} \mathrm{Ar} \\
\text { plagioclase }\end{array}$ & $\mathrm{U} / \mathrm{Pb}$ zircon \\
\hline Holyoke Basalt & & & & & $199.3 \pm 1.2^{9}$ & \\
\hline Talcott Basalt & $186 \pm 3^{4}$ & $186 \pm 8^{4}$ & & & $187 \pm 10^{4}$ & \\
\hline \multirow[t]{3}{*}{ North Mountain Basalt (NMB) } & & & & $201 \pm 2.5^{8}$ & $201.0 \pm 1.4^{9}$ & $201.7 \pm 1.4^{10}$ \\
\hline & & & & $200.8 \pm 2.2^{8}$ & $198.9 \pm 0.7^{8}$ & $201.27 \pm 0.06^{11}$ \\
\hline & & & & & & $201.38 \pm 0.02^{12}$ \\
\hline Higganum Dyke & $194 \pm 12^{3}$ & & & $201.2 \pm 2.4^{1}$ & & \\
\hline Christmas Cove Dyke & $191 \pm 10^{2}$ & & & $196.4-204.8^{1}$ & & \\
\hline Caraquet Dyke & $191 \pm 2^{6}$ & & & $201.5 \pm 2.4^{1}$ & & \\
\hline Ministers Is. Dyke & $189 \pm 8^{5}$ & & & & & \\
\hline Shelburne Dyke & $193 \pm 2^{6}$ & & $202 \pm 3^{7}$ & & & \\
\hline
\end{tabular}

References: ${ }^{1}$ this paper; ${ }^{2}$ Weston Geophysical 1977; ${ }^{3}$ Armstrong and Besancon 1970; ${ }^{4}$ Seiderman et al $.1984 ;{ }^{5}$ Stringer and Burke 1985; ${ }^{6}$ Hodych and Hayatsu $1988 ;{ }^{7}$ Dunn et al . 1998; ${ }^{8}$ Kontak and Archibald 2003; ${ }^{9}$ Jourdan et al . 2009; ${ }^{10}$ Hodych and Dunning 1992; ${ }^{11}$ Schaltegger et al . 2008; ${ }^{12}$ Schoene et al . 2010. 


\section{Higganum Dyke}

A single sample of the Higganum Dyke collected from central Connecticut yielded a slightly discordant spectrum (Fig. 9b) with plateau (201.7 Ma) and isotope correlation (200.2 Ma) ages slightly younger than the total gas age (204.6 Ma). Both the "saddle shape" of the age spectrum and the ${ }^{40} \mathrm{Ar} /{ }^{36} \mathrm{Ar}$ intercept ( 315 versus the current atmospheric value of 295.5) on the isotope correlation diagram (not shown) suggests a small amount of excess ${ }^{40} \mathrm{Ar}$ contamination which would explain the slightly older total gas age. The age of emplacement of the Higganum Dyke is therefore taken to be $201.2 \pm 2.8 \mathrm{Ma}$ which is the average of the plateau and isotope correlation ages.

\section{Christmas Cove Dyke}

Three samples of the Christmas Cove dyke (DP-1, MR-1, SP-1), each collected from a different locality, were analyzed and yielded variably discordant age spectrum. Both samples MR-1 (Fig. 9d) and SP-1 (Fig. 9e) have highly discordant age spectra (both somewhat "saddle shaped") that suggest complex argon systematics in these whole rock samples. MR-1 displays ages (total gas, isotope correlation, weighted average age) that are consistently 10 to $15 \mathrm{Ma}$ older than the ages from sample SP-1. Given the complicated argon systematics suggested by these results, and that these two samples are from the same dyke and should yield the same age, we will refrain from making any estimates of the timing of Christmas Cove Dyke emplacement based on the data from these two samples.

DP-1 (Fig. 9c) shows the least discordance of the three Christmas Cove Dyke samples and we prefer to base our emplacement age estimate on the results from this sample. While not as discordant as MR-1 and SP-1, individual apparent ages from consecutive increments in DP-1 are still too dissimilar to calculate a plateau age by the strict criteria of Fleck et al. (1977). However, a weighted average age of 203.1 Ma for four consecutive increments of similar age (61\% of ${ }^{39} \mathrm{Ar}$ released) is in close agreement with the isotope correlation age $(203.6 \pm 2.6 \mathrm{Ma})$ from this sample. The total gas age of this sample $(205.3 \mathrm{Ma})$ is slightly older than these two ages due primarily to a large final age increment (22\% of total $39 \mathrm{Ar}$ released) that has an older apparent age (209.1 Ma). Based on these results, we tentatively interpret the emplacement age of the Christmas Cove dyke to be the isotope correlation age of $203.6 \pm 2.6 \mathrm{Ma}$.

In summary, we interpret our ${ }^{40} \mathrm{Ar} /{ }^{39} \mathrm{Ar}$ results to indicate the Caraquet Dyke was emplaced at $201.5 \pm 2.4$ $\mathrm{Ma}$, the Higganum dyke emplaced at $201.2 \pm 2.8 \mathrm{Ma}$, and while complex argon systematics render this interpretation less certain, the Christmas Cove was emplaced at 203.6 \pm 2.6
Ma. When the analytical uncertainties of each of these ages are considered, all overlap, and the argon data are consistent with our interpretation that all three were emplaced at around the same time. These dates are generally close to recent ${ }^{40} \mathrm{Ar} /{ }^{39} \mathrm{Ar}$ and $\mathrm{U}-\mathrm{Pb}$ dates for other dykes and basalts assigned to the CAMP in the New England-Maritimes region, as summarized in Table 4.

\section{DISCUSSION}

Petrogenetic studies using trace elements and isotopes have been performed for the Ministers Island Dyke of southern New Brunswick (Dunn and Stringer 1990), the Onway Dyke of southern New Hampshire (Dorais et al. 2005), and the Higganum Dyke of southern New England (Philpotts and Martello 1986). In addition to field mapping and descriptive petrology, our petrographic and whole-rock chemical analyses, with support from radiometric dates, show that these regional dykes are probably co-magmatic with the Christmas Cove Dyke and are members of the same dyke system, which represents the source of the initial tholeiitic flood basalts in Early Mesozoic rift basins (Fig. 8 and Table 4).

Analyses of minerals and isotope chemistry from other studies of correlated dykes are equally applicable to the Christmas Cove Dyke and we have not repeated that work. Essentially the dyke magma is found to be derived from the lower lithospheric mantle after a past enrichment event involving subduction of crustal materials into the source region, as discussed by Dostal and Durning (1998) and Murphy et al. (2011) for the Atlantic Canada region, by Pegram (1990) for the greater area of eastern North American basalts, and by Puffer (2003) for the entire Central Atlantic Magmatic Province. In addition, Murphy et al. (2011) argue that mantle sources for basalts in Atlantic Canada are essentially unchanged since the Neoproterozoic. Consequently, long-distance horizontal transport of magma from other mantle sources, or generation of magma from deep-mantle plumes is unlikely since over time both would have resulted in chemical and isotopic variations that are not observed. McHone (2000) discussed additional reasons why magmatism related to the opening of the North Atlantic Ocean is not explained by a deep mantle plume model. A similar conclusion is based on a more comprehensive study of isotopic and trace elements in the northeastern North American CAMP by Renaud et al. (2014), who see no evidence or requirement for a central deep-mantle plume source.

Many attempts have been made to derive the different tholeiites of regional dykes and basins from one or more "parent" magmas, or from each other (Weigand and Ragland 1970; Dostal and Durning 1998). Models that have been proposed include various combinations of fractional 


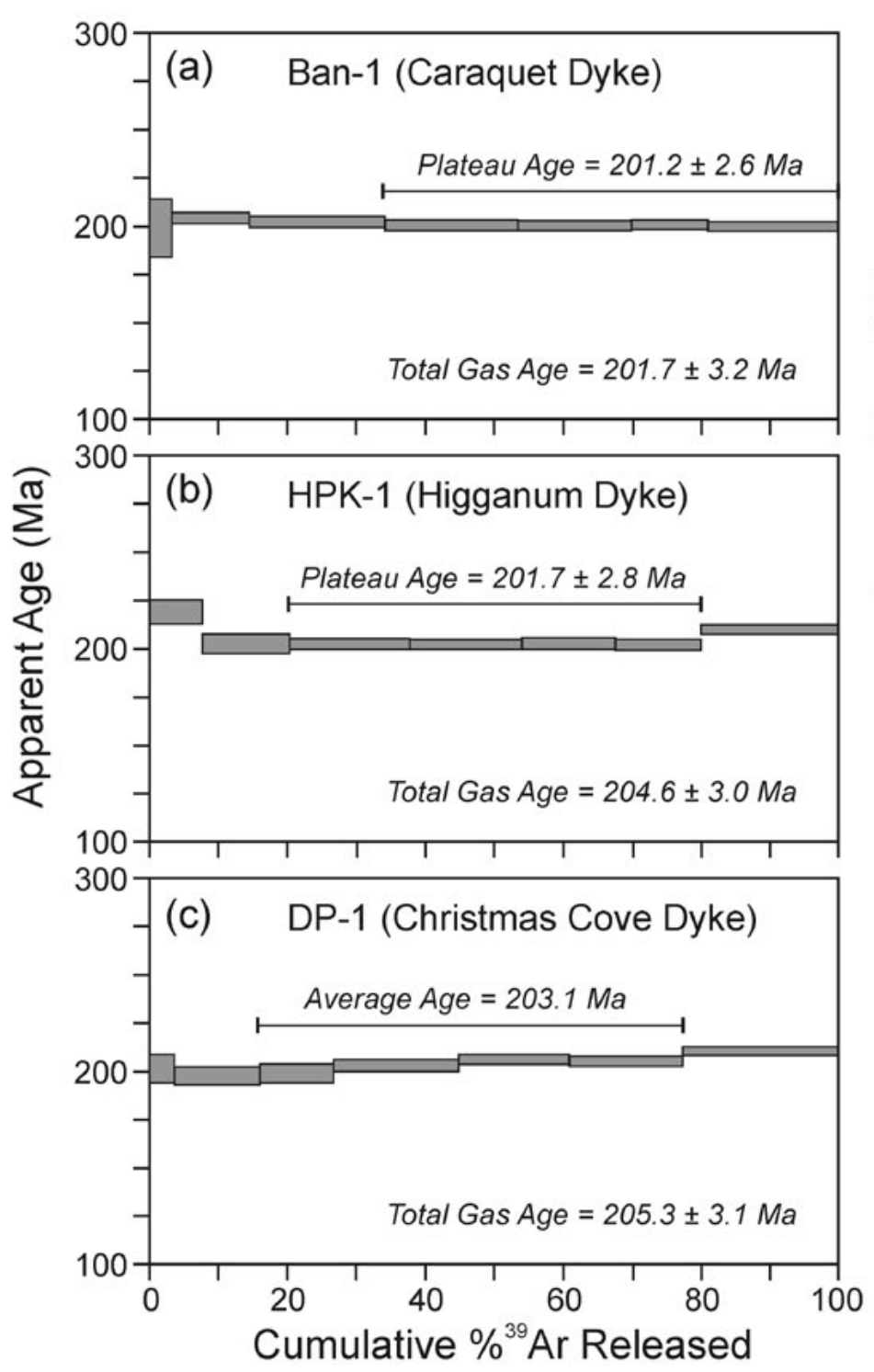

crystallization in sub-crustal magma chambers, flow differentiation in dykes and lavas, contamination by crustal wall rocks, and a filter-pressed crystal lattice mechanism (Kontak 2008). Each of these models has support from observations and experiments on samples from individual dykes or flows, but there continues to be little direct evidence to link all of the different dyke and lava systems to a common magma parent. In contrast, many studies show that at least some magma types cannot be related through reasonable differentiation processes (e.g., Tollo and Gottfried 1989; Dorais et al. 2005). There is also no physical evidence such as large plutons that might represent chambers in which these basalts could fractionate within the crust. Yet, levels of $\mathrm{Mg}$ and other chemical components in each dyke system show that these magmas have evolved far from any melts in equilibrium with olivine-rich mantle sources. In addition, the CAMP magmas are mantle melts that formed close to one another in time and space, although they physically

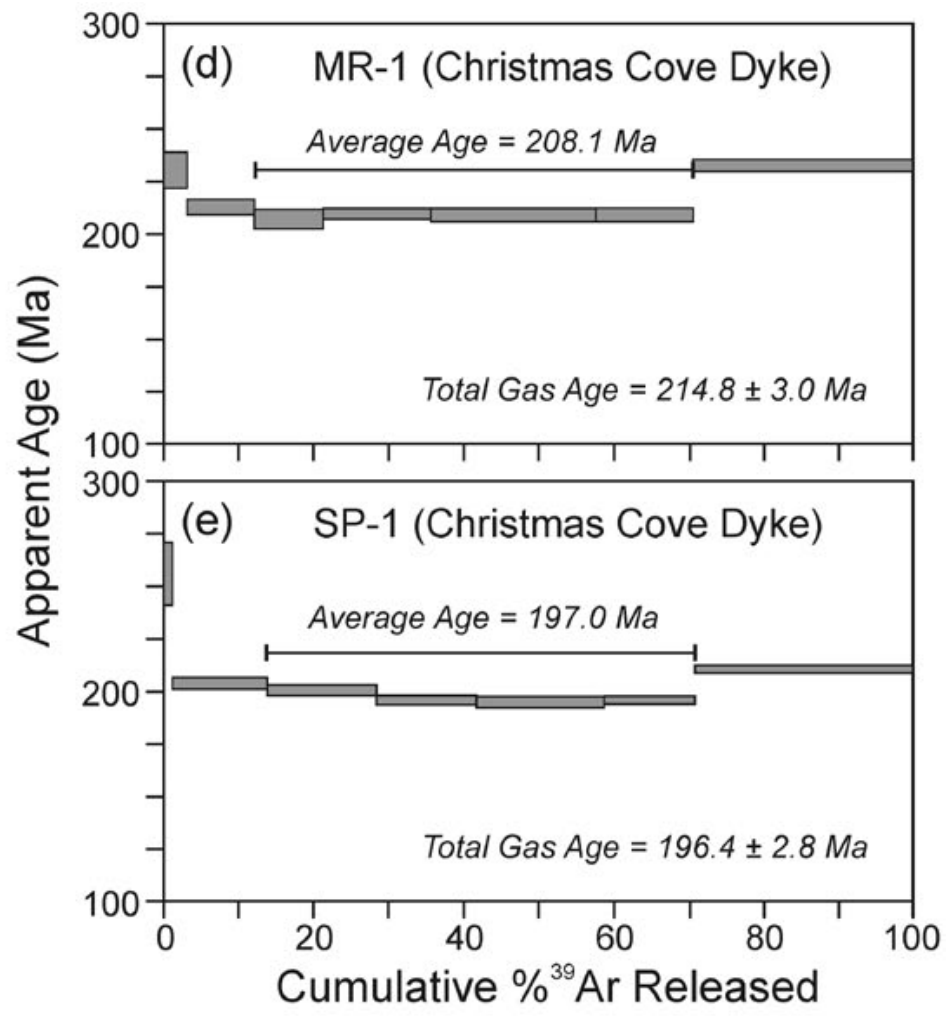

Figure 9. ${ }^{40} \mathrm{Ar} /{ }^{39} \mathrm{Ar}$ plateau age spectra for five whole-rock dyke samples. See the text for descriptions and Appendix $B$ for analytical data.

overlap in northeastern North America only as lava flows within Mesozoic basins.

Tollo and Gottfried (1986) and McHone (1996) concluded from petrochemical and geographical arguments that the different groups of basaltic rocks are not derived from a common magma by differentiation, but rather each represents a distinct mantle source and/or melting event. Magma types present in dykes and basalts are very similar in widely separated areas of eastern North America and the CAMP, as well as being uniform for hundreds of kilometres along individual dykes. It is too unlikely that variable fractionation and crustal contamination of individual magmas derived from several magma chambers at depth would allow them to match so perfectly, and one such chamber is not a reasonable source for different dykes forming across such great distances in a heterogeneous mantle. Instead, similar melts may be derived from specific layers or horizons of similar mantle compositions at similar 
depths and temperatures (Meibom et al. 2002). The dyke magmas intruded fractures that propagated both vertically to the surface and horizontally, according to extensional stresses in the lower lithosphere as well as buoyancy pressures. Upper crustal features, including basin faults and terrane boundaries, show little influence over the greater dyke locations and paths, except at a very local and minor scale.

\section{SIGNIFICANCE AS A FLOOD BASALT SOURCE}

The Talcott Basalt of the Hartford Basin has a similar lithostratigraphy and close petrological correlation with the very large North Mountain Basalt of the Fundy Basin between New Brunswick and Nova Scotia, Canada (McHone 1996; Olsen 1997). The western side of the Fundy Basin is near the Ministers Island Dyke (Fig. 2), which we find to be petrologically similar to the Christmas Cove Dyke, but because of its relatively small size the Ministers Island Dyke has been discounted as a reasonable source for the North Mountain Basalt in several studies (Wade et al. 1996; PePiper and Piper 1999; Kontak 2008). However, the much larger Lepreau River Dyke has been subsequently mapped and could add to the similar Ministers Island Dyke for producing the Fundy Basin basalts, and a correlation with the Christmas Cove Dyke is also reasonable (McHone 2011; McHone and Barr 2003). In that case, the Christmas Cove Dyke (and possible continuity with the Lepreau River Dyke) represents a physical connection between the Hartford and Fundy basins and a co-magmatic source for the Late Triassic flood basalts.

A correlation of source dykes with their flood basalt products in the Hartford and Fundy basins (Philpotts and Martello 1986) places them into a detailed chrono-stratigraphic sequence based on Milankovitch cyclostratigraphy (Olsen 1997), which indicates the Christmas Cove - Higganum dyke system is older by about 300,000 years than the Caraquet - Buttress dyke system. Moreover, there is a younger-to-older intrusional sequence of west-to-east for the three large dyke systems of southern New England. As we have shown, the Buttress-Caraquet and Higganum-Christmas Cove dyke systems continue into northern New England and New Brunswick, where they turn more eastward and diverge along their trends (Fig. 2).

Several hundred kilometres to the east of the Christmas Cove Dyke is the Shelburne Dyke of Nova Scotia, which is a very large intrusion that extends into the eastern Gulf of Maine but does not appear in New England (Fig. 2; Papezik and Barr 1981). As observed by Pe-Piper and Piper (1999) and Kontak (2008), lavas derived from the Shelburne dyke have not been recognized in the Fundy Basin. The large Late Paleozoic South Mountain batholith of southern Nova
Scotia could have presented a topographic barrier between the basin and the Shelburne dyke in Early Mesozoic time (it remains a high area today), so that Shelburne lavas did not flow into areas that are currently exposed. Such lavas may instead be preserved in submarine basins south and east of Nova Scotia (Hutchinson et al. 1988). If the west-toeast progression of younger to older ages continues into this region (Fig. 2), the Shelburne Dyke could be older than the Christmas Cove Dyke. Support for an older age has been presented by Dunn et al. (1998), who reported a ${ }^{40} \mathrm{Ar} /{ }^{39} \mathrm{Ar}$ age of $203 \pm 2 \mathrm{Ma}$ for both the Shelburne dyke and the Messejana dyke system of Spain and Portugal. They regarded both dykes as essentially co-magmatic, if not formerly connected. An older age also suggests the possibility that the Shelburne-Messejana magmatic event may precede or be synchronous with the end-Triassic mass extinction (ages detailed by Blackburn et al. 2013).

In addition to assisting to map portions of the same dyke set along a great distance, the bulk chemistry of different generations of dykes can be used to correlate them with other Central Atlantic Magmatic Province basalts preserved within Early Mesozoic rift basins (Table 5).

As we relate, the Higganum-Christmas Cove dyke system is exposed for about $700 \mathrm{~km}$ from Long Island Sound to the western Gulf of Maine, (and potentially farther), forming a magmatic connection between the Hartford and Fundy rift basins. An extensive dyke fissure this large could have produced massive basalt flows covering both of those rift basins, as well as the areas in between (e.g., Swanson et al. 1975; Self et al. 1997). McHone (1996) proposed that similar basalts in basins of New Jersey to Pennsylvania (USA) are also linked to this great "initial Pangaean" flood basalt event of northeastern North America, with perhaps 50,000 km of tholeiite extruded over an area of at least $500,000 \mathrm{~km}^{2}$. A volcanic event of this size must have had severe consequences for the Late Triassic world environment (McHone 2003). If large dykes in Spain, Morocco, and elsewhere (Bertrand 1991) were also active or nearly synchronous with this volcanism, the volume and area of this flood basalt would have been much greater. Because dyke systems vary in their ages across the northern CAMP, whether or not they have similar magma types, there may have been massive flood basalt eruptions in other areas that are older as well as younger than the basalts of the Hartford and Fundy basins.

\section{SUMMARY OF CONCLUSIONS}

1. The Christmas Cove Dyke is mapped for $190 \mathrm{~km}$ along the coast of Maine, USA, with intermittent but co-linear 13 to $35 \mathrm{~m}$ wide exposures of columnar dolerite. The dolerite is orthopyroxene-bearing quartz tholeiite of an "HTQ" type, and its age, mineralogy, chemistry, and geographic extent indicate that the Christmas Cove Dyke is contiguous 
Table 5. Large dykes and correlated flood basalts of the northern CAMP.

\begin{tabular}{|c|c|c|c|c|c|c|c|}
\hline Source Dyke & $\begin{array}{l}{ }^{1} \text { York } \\
\text { Haven }\end{array}$ & $\begin{array}{c}{ }^{2} \text { Palisades } \\
\text { Sill }\end{array}$ & $\begin{array}{c}{ }^{3} \text { Higganum } \\
\text { Holden }\end{array}$ & $\begin{array}{c}{ }^{4} \text { Christmas } \\
\text { Cove }\end{array}$ & $\begin{array}{c}{ }^{5} \text { Ministers } \\
\text { Island }\end{array}$ & $\begin{array}{l}{ }^{6} \text { Foum } \\
\text { Zguid }\end{array}$ & ${ }^{7}$ Messejana \\
\hline $\mathrm{SiO}_{2}$ (wt. \%) & 51.84 & 51.98 & 52.62 & 52.58 & 52.94 & 51.99 & 52.07 \\
\hline $\mathrm{TiO}_{2}$ & 1.09 & 1.22 & 1.17 & 1.15 & 1.14 & 1.10 & 1.04 \\
\hline $\mathrm{Al}_{2} \mathrm{O}_{3}$ & 14.34 & 14.48 & 14.96 & 14.47 & 14.13 & 15.05 & 15.90 \\
\hline $\mathrm{FeO}^{*}$ & 9.93 & 10.19 & 10.20 & 10.53 & 10.05 & 9.52 & 9.28 \\
\hline $\mathrm{MnO}$ & 0.20 & 0.18 & 0.17 & 0.18 & 0.20 & 0.18 & 0.16 \\
\hline $\mathrm{MgO}$ & 7.72 & 7.59 & 7.59 & 7.81 & 7.92 & 7.69 & 7.16 \\
\hline $\mathrm{CaO}$ & 10.73 & 10.33 & 10.94 & 10.57 & 10.94 & 11.75 & 11.51 \\
\hline $\mathrm{Na}_{2} \mathrm{O}$ & 1.96 & 2.04 & 2.33 & 1.98 & 1.97 & 1.97 & 2.16 \\
\hline $\mathrm{K}_{2} \mathrm{O}$ & 0.60 & 0.84 & 0.56 & 0.60 & 0.55 & 0.60 & 0.58 \\
\hline $\mathrm{P}_{2} \mathrm{O}_{5}$ & 0.12 & & 0.20 & 0.13 & 0.14 & 0.15 & 0.14 \\
\hline $\begin{array}{c}\text { Basalt } \\
\text { Product }\end{array}$ & $\begin{array}{l}{ }^{8} \text { Mt. Zion } \\
\text { Church }\end{array}$ & $\begin{array}{l}{ }^{9} \text { Orange } \\
\text { Mountain }\end{array}$ & ${ }^{10}$ Talcott & $?$ & $\begin{array}{l}{ }^{11} \text { North } \\
\text { Mountain }\end{array}$ & $\begin{array}{l}{ }^{12} \text { High } \\
\text { Atlas }\end{array}$ & $?$ \\
\hline $\mathrm{SiO}_{2}$ (wt. \%) & 51.37 & 51.45 & 51.86 & & 52.16 & 51.06 & \\
\hline $\mathrm{TiO}_{2}$ & 1.18 & 1.02 & 1.07 & & 1.06 & 1.06 & \\
\hline $\mathrm{Al}_{2} \mathrm{O}_{3}$ & 14.24 & 14.34 & 14.27 & & 14.29 & 14.84 & \\
\hline $\mathrm{FeO}^{*}$ & 10.86 & 10.36 & 10.86 & & 10.35 & 10.33 & \\
\hline $\mathrm{MnO}$ & 0.17 & 0.15 & 0.16 & & 0.16 & 0.19 & \\
\hline $\mathrm{MgO}$ & 7.58 & 8.19 & 7.98 & & 7.05 & 8.17 & \\
\hline $\mathrm{CaO}$ & 10.78 & 10.86 & 11.24 & & 10.35 & 12.25 & \\
\hline $\mathrm{Na}_{2} \mathrm{O}$ & 2.05 & 2.10 & 2.06 & & 2.39 & 1.69 & \\
\hline $\mathrm{K}_{2} \mathrm{O}$ & 0.21 & 0.54 & 0.50 & & 0.60 & 0.49 & \\
\hline $\mathrm{P}_{2} \mathrm{O}_{5}$ & 0.13 & 0.13 & & & 0.16 & 0.16 & \\
\hline
\end{tabular}

References: this paper; Bertrand 1991; Dunn and Stringer 1990; Philpotts and Martello 1986; Puffer 1992; Smith et al . 1975. Each of the above are averages of four to ten analyses. Locations: ${ }^{1}$ southern Pennsylvania, USA; ${ }^{2}$ eastern New jersey, USA; ${ }^{3}$ eastern Connecticut and Massachusetts, USA; ${ }^{4}$ southern Maine, USA; ${ }^{5}$ southwestern New Brunswick, Canada; ${ }^{6}$ southeastern Morocco; ${ }^{7}$ Portugal and Spain; ${ }^{8}$ Culpeper Basin of Northern Virginia, USA; ${ }^{9}$ Newark Basin of New Jersey, USA;

${ }^{10}$ Hartford Basin of Connecticut, USA; ${ }^{11}$ Fundy Basin of Nova Scotia and New Brunswick, Canada;

${ }^{12}$ Argana Basin of Morocco. Question mark signifies that basalt products are undetermined.

and co-magmatic with the Onway Dyke of southern New Hampshire, the Holden Dyke of Massachusetts, the Higganum Dyke of southern New England, and probably dykes in southern New Brunswick, Canada; all parts of a giant dyke system at least $700 \mathrm{~km}$ long.

2. The southern part of the dyke system is the source of the Talcott Basalt, the initial (earliest) lava preserved in the Hartford Basin of Connecticut. Because the Talcott Basalt is tightly correlated and apparently co-magmatic with basalt in the Fundy Basin, Newark Basin, and possibly other basins in eastern North America, the Higganum-Christmas Cove dyke system and potential extensions represent a giant fissure source for the earliest basalts within and formerly outside of the basins. Because of that correlation, a precise $\mathrm{U}-\mathrm{Pb}$ zircon date of $201.38 \pm 0.02 \mathrm{Ma}$ (Schoene et al. 2010) and finding of end-Triassic relative age (Cirilli et al. 2009) for the North Mountain Basalt can also apply to the Christmas Cove dyke system and its flood basalts, as allowed by our ${ }^{40} \mathrm{Ar} /{ }^{39} \mathrm{Ar}$ dates.

3. Two other large dykes in southern New England (the Buttress and Bridgeport dykes) are linked to the middle and upper flood basalts in the Hartford Basin, which are roughly 300,000 years apart in age as shown by stratigraphy. By these connections, the three dyke systems must progress 
in age from younger to older, west to east. The dykes diverge northeastward through southern New England, and the mid-aged Buttress - Ware Dyke trends toward the Caraquet Dyke of central New Brunswick and Maine, which has similar petrology and age. Dyke ages may progress the same way from Maine into maritime Canada, so that the Shelburne Dyke of southern Nova Scotia may be somewhat older than the Christmas Cove Dyke and North Mountain Basalt, which are likewise older than the Caraquet Dyke. Such timing differences create distributional patterns among basalts, sills, and dykes of end-Triassic to Early Jurassic ages around the central Atlantic rift basins of northeastern North America, northwestern Africa, southwestern Europe, and possibly other areas of the Central Atlantic Magmatic Province.

\section{ACKNOWLEDGMENTS}

Sandra Barr and Anthony Philpotts assisted with thin sections and chemical data used in this study, and we thank them for much additional information and encouragement. Daniel Lux provided facilities of the University of Maine radiometric isotope lab for argon dates. Andrew Lindsey and Jelle de Boer located and described the dyke at Whitehead Island. Nancy McHone, Chris White, Michael Dorais, Daniel Kontak, Jelle de Boer, John Puffer, Paul Olsen, Daniel Sundeen, and Paul Ragland provided many useful discussions and other assistance. We appreciate the helpful comments and reviews of the manuscript by John Greenough and Jarda Dostal.

\section{REFERENCES}

Armstrong, R. L. and Besancon, J. 1970. A Triassic timescale dilemma: K-Ar dating of Upper Triassic mafic igneous rocks, eastern U.S.A. and Canada and post Upper Triassic plutons, western Idaho, U.S.A. Eclogae Geologica Helvetiae, 63, pp. 15-28.

Bascom, Florence. 1899. On some dikes in the vicinity of Johns Bay, Maine. American Geologist, 19, pp. 275-280.

Berry. H.N. and Hussey, A.M. II. (Editors). 1998. Bedrock geology of the Portland 1:100,000 quadrangle, Maine and New Hampshire. Augusta, Maine Geological Survey, Open-File Map 98-1.

Bertrand, H. 1991. The Mesozoic tholeiitic province of northwest Africa: A volcano-tectonic record of the early opening of the central Atlantic. In Magmatism in extensional structural settings. Edited by A. Kampunzu. New York, Springer Verlag, pp. 147-191. http://dx.doi. org/10.1007/978-3-642-73966-8_7

Blackburn, T.J., Olsen, P.E., Bowring, S.A., McLean, N.M.,
Kent, D.V., Puffer,J., McHone, J.G., Rasbury, E.T., and EtTouhami, M. 2013. Zircon U-Pb Geochronology Links the End-Triassic Extinction with the Central Atlantic Magmatic Province. Science, 340, no. 6135, pp. 941-945. http://dx.doi.org/10.1126/science.1234204

Boucot, A.J., Griscom, A., and Allingham, J.W. 1964. Geologic and Aeromagnetic Map of Northern Maine: U.S. Geological Survey, Geophysical Investigations Map GP312, scale 1:250 000 .

Burke, K.B.S., Hamilton, J.B., and Gupta, V.K. 1973. The Caraquet Dyke: Its Tectonic Significance: Canadian Journal of Earth Sciences, 10, pp. 1760-1768. http:// dx.doi.org/10.1139/e73-172

Cirilli, S., Marzoli, A., Tanner, L., Bertrand, H., Buratti, N., Jourdan, F., Bellieni, G., Kontak, D., and Renne, P.R. 2009. Latest Triassic onset of the Central Atlantic Magmatic Province (CAMP) volcanism in the Fundy Basin (Nova Scotia): new stratigraphic constraints. Earth and Planetary Science Letters, 286, pp. 514-525. http:// dx.doi.org/10.1016/j.epsl.2009.07.021

Dalrymple, G.B., Alexander, E.C., Jr., Lanphere, M.A., and Kracker, G.P. 1981. Irradiation of samples for ${ }^{40} \mathrm{Ar} /{ }^{39} \mathrm{Ar}$ dating using the Geological Survey TRIGA reactor. U.S. Geological Survey Professional Paper 1176, 55 p.

de Boer, J.Z., Ernst, R.E., and Lindsey, A.G. 2003. Evidence for predominate lateral magma flow along major feederdyke segments of the eastern North American swarm based on magnetic fabric. In The Great Rift Valleys of Pangea in Eastern North America. Edited by P.M. LeTourneau and P.E. Olsen, Columbia University Press, 1, pp. 189-206.

Deenen, M.H.L., Ruhl, M., Bonis, N.R., Krijgsman, W., Kuerschner, W.M., Reitsma, M., and Van Bergen, M.J. 2010. A new chronology for the end-Triassic mass extinction. Earth and Planetary Science Letters, 291, pp.113-125. http://dx.doi.org/10.1016/j.epsl.2010.01.003

Dorais, M.J., Harper, M., Larson, S., Nugroho, H., Richardson, P., and Roosmawati, N. 2005. A comparison of Eastern North America and Coastal New England magma suites: implications for subcontinental mantle evolution and the broad-terrane hypothesis. Canadian Journal of Earth Sciences, 42, pp. 1571-1587. http:// dx.doi.org/10.1139/e05-056

Dostal, J. and Durning, M. 1998. Geochemical constraints on the origin and evolution of early Mesozoic dykes in Atlantic Canada. European Journal of Mineralogy, 10, pp. 79-93.

Dunn, A.M., Reynolds, P.H., Clarke, D.B., and Ugidos, J.M. 1998. A comparison of the age and composition of the Shelburne dyke, Nova Scotia, and the Messejana dyke, Spain. Canadian Journal of Earth Sciences, 35, pp. 11101115. http://dx.doi.org/10.1139/e98-058

Dunn, T. and Stringer, P. 1990. Petrology and petrogenesis of the Ministers Island dyke, southwest New Brunswick, 
Canada. Contributions to Mineralogy and Petrology, 105, pp. 55-65. http://dx.doi.org/10.1007/BF00320966

Fleck, R.J., Sutter, J.F., and Elliot, D.H. 1977. Interpretation of discordant ${ }^{40} \mathrm{Ar} /{ }^{39} \mathrm{Ar}$ age spectra of Mesozoic tholeiites from Antarctica. Geochemica et Cosmochimica Acta, V. 41, p. 15-32. http://dx.doi.org/10.1016/00167037(77)90184-3

Greenough, J.D., and Papezik, V.S. 1986. Petrology and geochemistry of the early Mesozoic Caraquet dyke, New Brunswick, Canada. Canadian Journal of Earth Sciences, 23, pp. 193-201. http://dx.doi.org/10.1139/e86-022

Hodych, J.P. and Dunning, G.R. 1992. Did the Manicouagan impact trigger end-of-Triassic mass extinction? Geology, 20, pp. 51-54. http://dx.doi.org/10.1130/00917613(1992)020<0051:DTMITE >2.3.CO;2

Hodych, J.P. and Hayatsu, A. 1988. Paleomagnetism and $\mathrm{K}$-Ar isochron dates of Early Jurassic basaltic flows and dykes of Atlantic Canada. Canadian Journal of Earth Sciences, 25, pp. 1972-1989. http://dx.doi.org/10.1139/ e88-185

Hussey, A.M., II. 1971. Geologic map and cross-sections of the Orrs Island 7 1/2 minute quadrangle and adjacent area, Maine. Augusta, Maine Geologic Survey, Map GM2, 18 p, scale 1:24 000 .

Hussey, A.M. II and Marvinney, R.G. (Editors). 2002. Bedrock geology of the Bath 1:100 000 quadrangle, Maine. Augusta, Maine Geological Survey, Open-File Map 02-152.

Hutchinson, D.R., Klitgord, K.D., Lee, M.W., and Trehu, A.M. 1988. U.S. Geological Survey deep seismic reflection profile across the Gulf of Maine. Geological Society of America Bulletin, 100, pp. 172-184. http://dx.doi. org/10.1130/0016-7606(1988)100<0172:USGSDS>2.3 . $\mathrm{CO} ; 2$

Irvine, T.N. and Baragar, W.R.A. 1971. A guide to the chemical classification of the common volcanic rocks. Canadian Journal of Earth Sciences, 8, pp. 523-548. http://dx.doi.org/10.1139/e71-055

Jourdan, F., Marzoli, A, Bertrand, H., Cirilli, S., Tanner, L.H., Kontak, D.J., McHone, J.G., Renne, P.R., and Bellieni, G. 2009. ${ }^{40} \mathrm{Ar} /{ }^{39} \mathrm{Ar}$ ages of CAMP in North America: Implications for the Triassic-Jurassic boundary and the ${ }^{40} \mathrm{~K}$ decay constant bias. Lithos, 110, pp. 167-180. http:// dx.doi.org/10.1016/j.lithos.2008.12.011

Kontak, D.J. 2008. On the edge of CAMP: geology and volcanology of the Jurassic North Mountain Basalt, Nova Scotia. Lithos, 101, pp. 74-101. http://dx.doi. org/10.1016/j.lithos.2007.07.013

Kontak, D.J., DeWolfe, M., and Dostal, J. 2002. Late-stage crystallization history of the Jurassic North Mountain Basalt, Nova Scotia: I. Evidence for pervasive silicateliquid immiscibility. Canadian Mineralogist, 40, pp. 12871311. http://dx.doi.org/10.2113/gscanmin.40.5.1287

Kontak D.J. and Archibald, D.A. 2003. ${ }^{40} \mathrm{Ar} /{ }^{39} \mathrm{Ar}$ age of the
Jurassic North Mountain Basalt, southwestern Nova Scotia. Atlantic Geology, 39, pp. 47-53.

LeBas, M.J., LeMaitre, R.W., Streckeisen, A., and Zanettin, B. 1986. A chemical classification of volcanic rocks based on the total alkali silica diagram. Journal of Petrology, 27, pp. 745-750. http://dx.doi.org/10.1093/petrology/27.3.745

McHone, J.G. 1984. Mesozoic igneous rocks of northern New England and adjacent Quebec. Geological Society of America, Map and Chart Series MC-49, scale 1:390 000, 5 p. text.

McHone, J.G. 1988. Tectonic and paleostress patterns of Mesozoic intrusions in eastern North America. In Triassic-Jurassic Rifting: Continental Breakup and the Origin of the Atlantic Ocean and Passive Margins, Part B. Edited by W.R. Manspeizer. New York, Elsevier, pp. 607-619. http://dx.doi.org/10.1016/B978-0-444-429032.50030-0

McHone, J.G. 1992. Mafic dike suites within Mesozoic igneous provinces of New England and Atlantic Canada. In Eastern North American Mesozoic Magmatism. Edited by J.H. Puffer and P.C. Ragland. Geological Society of America Special Paper 268, pp. 1-11. http://dx.doi. org/10.1130/SPE268-p1

McHone, J.G. 1993. Tholeiitic great dikes across New England and Atlantic Canada. Geological Society of America, Abstracts with Programs, 25, p. 55.

McHone, J.G. 1996. Broad-terrane Jurassic flood basalts across northeastern North America. Geology, 24, pp. 319-322. http://dx.doi.org/10.1130/00917613(1996)024<0319:BTJFBA >2.3.CO;2

McHone, J.G. 2000. Non-plume magmatism and tectonics during the opening of the central Atlantic Ocean. Tectonophysics, 316, pp. 287-296. http://dx.doi. org/10.1016/S0040-1951(99)00260-7

McHone, J.G. 2003. Volatile emissions of Central Atlantic Magmatic Province basalts: Mass assumptions and environmental consequences. In The Central Atlantic Magmatic Province. Edited by W.E. Hames, J.G. McHone, P.R. Renne, and C. Ruppel. American Geophysical Union Monograph 136, pp. 241-254. http://dx.doi. org/10.1029/136GM013

McHone, J.G. 2011. Triassic basin stratigraphy at Grand Manan, New Brunswick, Canada. Atlantic Geology, 47, pp. 125-137. http://dx.doi.org/10.4138/atlgeol.2011.006

McHone, J.G. and Sundeen, D.A. 1995. Mesozoic intrusions in southeastern New Hampshire. In Field Guide for the New England Intercollegiate Geological Conference. Edited by A.M. Hussey, II. Brunswick, Maine, Trip C-2, $20 \mathrm{p}$.

McHone, J.G. and Barr, S.M. 2003. Fissure dike sources for the North Mountain Basalt Group, Fundy Basin. Geological Society of America, Northeastern Section Abstracts with Programs, 35, p. 41.

Meibom, A., Sleep, N.H., Chamberlain, C.P., Coleman, 
R.G., Frei, R., Hren, M.T., and Wooden, J.L. 2002. ReOs isotopic evidence for long-lived heterogeneity and equilibrium processes in Earth's upper mantle. Nature, 419, pp. 705-708. http://dx.doi.org/10.1038/nature01067

Murphy, J.B., Dostal J., Gutiérrez-Alonso, G., and Keppie, J.D. 2011. Early Jurassic magmatism on the northern margin of CAMP: Derivation from a Proterozoic subcontinental lithospheric mantle. Lithos, 123, pp. 158-164. http://dx.doi.org/10.1016/j.lithos.2010.12.002

Olsen, P. E. 1997. Stratigraphic record of the early Mesozoic breakup of Pangea in the Laurasia-Gondwana rift system. Annual Review of Earth and Planetary Sciences, 25, pp. 337-401. http://dx.doi.org/10.1146/annurev. earth.25.1.337

Osberg, P.H., Hussey, A.M., II, and Boone, G.M. 1985. Bedrock Geologic Map of Maine. Augusta, Maine Geological Survey, scale 1:500 000.

Papezik, V.S., and Barr, S.M. 1981. The Shelburne dyke, an early Mesozoic diabase dyke in Nova Scotia: Mineralogy, petrology, and regional significance. Canadian Journal of Earth Sciences, 18, pp. 1346-1355. http://dx.doi. org/10.1139/e81-124

Pegram, W.J. 1990. Development of continental lithospheric mantle as reflected in the chemistry of the Mesozoic Appalachian tholeiites, U.S.A. Earth and Planetary Science Letters, 97, pp. 316-331. http://dx.doi.org/10.1016/0012821X(90)90049-4

Pe-Piper, G. and Piper, D.J.W. 1999. Were Jurassic tholeiitic lavas originally widespread in southeastern Canada? A test of the broad terrane hypothesis. Canadian Journal of Earth Sciences, 36, pp. 1509-1516. http://dx.doi. org/10.1139/e99-059

Perry, P.P. 1994. Chemical and petrographic analysis of an early Jurassic mafic dyke, Swans Island, Maine. Geological Society of America, Northeastern Section Abstracts with Programs, 26, p. 66.

Philpotts, A.R. and Martello, A. 1986. Diabase feeder dikes for the Mesozoic basalts in southern New England. American Journal of Science, 286, pp. 105-126. http:// dx.doi.org/10.2475/ajs.286.2.105

Philpotts, A.R. and Asher, P.M. 1993. Wallrock melting and reaction effects along the Higganum diabase dike in Connecticut: contamination of a continental flood basalt feeder. Journal of Petrology, 34, pp. 1029-1058. http:// dx.doi.org/10.1093/petrology/34.5.1029

Puffer, J.H. 1992. Eastern North American flood basalts. In Eastern North American Mesozoic Magmatism. Edited by J.H. Puffer and P.C. Ragland. Geological Society of America Special Paper 268, pp. 95-118. http://dx.doi. org/10.1130/SPE268-p95

Puffer, J.H. 2003. A reactivated back-arc source for CAMP magma, in The Central Atlantic Magmatic Province: Insights from fragmented Pangea. In The Central Atlantic Magmatic Province. Edited by W.E. Hames, J.G. McHone,
P.R. Renne, and C. Ruppel, C. American Geophysical Union Monograph 136, pp. 241-254.

Renaud, M., Marzoli, A., Reisberg, L., Bertrand, H., Nemchin, A., Chiaradia, M., Callegaro, S., Jourdan, F., Bellieni, G., Kontak, D., Puffer, J., and McHone, G. 2014. $\mathrm{Sr}, \mathrm{Nd}, \mathrm{Pb}$ and $\mathrm{Os}$ isotope systematics of CAMP tholeiites from Eastern North America (ENA): Evidence of a subduction-enriched mantle source. Journal of Petrology, in press.

Rodgers, J. 1985. Bedrock geological map of Connecticut. Connecticut Geological and Natural History Survey, Connecticut Natural Resources Atlas Series, scale 1:125 000 .

Schaltegger, U., Guex, J., Bartolini, A., Schoene, B., and Ovtcharova, M. 2008. Precise U-Pb age constraints for end-Triassic mass extinction; its correlation to volcanism and Hettangian post-extinction recovery. Earth and Planetary Sciences Letters, 267, pp. 266-275. http:// dx.doi.org/10.1016/j.epsl.2007.11.031

Schoene, B., Guex, J., Bartolini, A., Schaltegger, U., and Blackburn, T.J. 2010. Correlating the end-Triassic mass extinction and flood basalt volcanism at the $100 \mathrm{ka} \mathrm{level}$. Geology, 38, pp. 387-390. http://dx.doi.org/10.1130/ G30683.1

Self, S., Thordarson, T., and Keszthelyi, L. 1997. Emplacement of continental flood basalt lava flows. In Large Igneous Provinces. Edited by J.J.Mahoney and M.F. Coffin. Continental, Oceanic, and Planetary Flood Volcanism. American Geophysical Union Monograph 100, pp. 381410.

Seiderman, D.E., Masterson, W.D., Dowling, M. P., and Turekian, K. K. 1984. K-Ar dates and ${ }^{40} \mathrm{Ar} /{ }^{39} \mathrm{Ar}$ age spectra for Mesozoic basalt flows of the Hartford Basin, Connecticut, and the Newark Basin, New Jersey. Geological Society of America Bulletin, 95, pp. 594-598. http://dx.doi.org/10.1130/0016-7606(1984)95<594:KDA $\mathrm{AAS}>2.0 . \mathrm{CO} ; 2$

Smith, R. c., II, Rose, A. W., and Lanning, R. M. 1975. Geology and geochemistry of Triassic diabase in Pennsylvania: Geological Society of America Bulletin, 86, pp. 943-955. http://dx.doi.org/10.1130/0016-7606(1975)86<943:GAG $\mathrm{OTD}>2.0 . \mathrm{CO} ; 2$

Steiger, R.H., and Jäger, E. 1977 Subcommission on geochronology, convention on the use of decay constants in geo- and cosmochronology: Earth and Planetary Science Letters, 36, pp. 359-362. http://dx.doi.org/10.1016/0012821X(77)90060-7

Stringer, P. and Burke, K.B.S. 1985. Structure in southwest New Brunswick. Field Guide Excursion 9. In Field Excursions, Vol III. Edited by R.K. Pickerill, C.K. Mawer, and L.R. Fyffe. Geological Association of Canada Mineralogical Association of Canada. $34 \mathrm{p}$.

Sundeen, D.A. and Huff, M.C. 1992. Petrography, petrology, and $\mathrm{K}-$ Ar geochronology of hypabyssal mafic and silicic 
Mesozoic igneous rocks in southeastern New Hampshire. In Eastern North American Mesozoic Magmatism. Edited by J.H. Puffer and P.C. Ragland. Geological Society of America Special Paper 268, pp. 75-94. http://dx.doi. org/10.1130/SPE268-p75

Sun S. and McDonough, W.F. 1989. Chemical and isotopic systematics of oceanic basalts: implications for mantle composition and processes. In Magmatism in the Ocean Basins. Edited by A. D. Saunders and M. J. Norry. Geological Society London, Special Publication 42, pp. 313-345.

Swanson, D.A., Wright, T.L. and Helz, R. 1975. Linear vent systems and estimated rates of magma production and eruption for the Yakima Basalt on the Columbia Plateau. American Journal of Science 275, pp. 877-905. http:// dx.doi.org/10.2475/ajs.275.8.877

Tollo, R.P. and Gottfried, D. 1989. Early Jurassic quartznormative magmatism of the Eastern North American province: evidence for independent magmas and distinct sources. International Association of Volcanology and Chemistry of the Earth's Interior, Continental Magmatism Abstracts, Bulletin 131, New Mexico Bureau of Mines and Mineral Resources, p. 31.

Wade, J.A., Brown, D.E., Traverse, A., and Fensome, R.A. 1996. The Triassic-Jurassic Fundy Basin, eastern Canada: regional setting, stratigraphy, and hydrocarbon potential. Atlantic Geology, 32, pp. 189-231.

West, D.P., Jr., Ludman, A., and Lux, D.R. 1992. Silurian age for the Pocomoonshine gabbro-diorite, southeastern Maine and its regional tectonic implications. American Journal of Science, 292, pp. 253-273. http://dx.doi. org/10.2475/ajs.292.4.253

West, D.P. Jr., Lux, D.R., and Hussey, A.M., II. 1993.
Contrasting thermal histories across the Flying Point fault, southwestern Maine: Evidence for Mesozoic displacement. Geological Society of America Bulletin, 105, pp. 1478-1490. http://dx.doi.org/10.1130/00167606(1993) 105<1478:CTHATF>2.3.CO;2

West, D.P., Jr., and McHone, J.G. 1997. Timing of Early Jurassic "feeder" dike emplacement, northern Appalachians: Evidence for synchronicity with basin basalts. Geological Society of America, Northeastern Section Abstracts with Programs, 29, p. 89.

West, D.P., Jr., Roden-Tice, M.K., Potter, J.K., and Barnard, N.Q. 2008. Assessing the role of orogen-parallel faulting in post-orogenic exhumation. Low-temperature thermochronology across the Norumbega fault system, Maine. Canadian Journal of Earth Sciences, 45, pp. 287301. http://dx.doi.org/10.1139/E07-073

Weston Geophysical. 1977. Geological and seismological investigations for Pilgrim Unit II of Boston Edison. U.S. Nuclear Regulatory Commission Document BE-SG7603, Appendix G-6, 19 p.

Weigand, P.W. and Ragland, P.C. 1970. Geochemistry of Mesozoic dolerite dikes from eastern North America. Contributions to Mineralogy and Petrology, 29, pp. 195214. http://dx.doi.org/10.1007/BF00373305

Wood, D.A. 1980. The application of a Th-Hf-Ta diagram to problems of tectonomagmatic classification and to establishing the nature of crustal contamination of basaltic lavas of the British Tertiary volcanic province. Earth and Planetary Science Letters, 50 (1), pp. 11-30. http://dx.doi. org/10.1016/0012-821X(80)90116-8

Editorial responsibility: Sandra M. Barr 


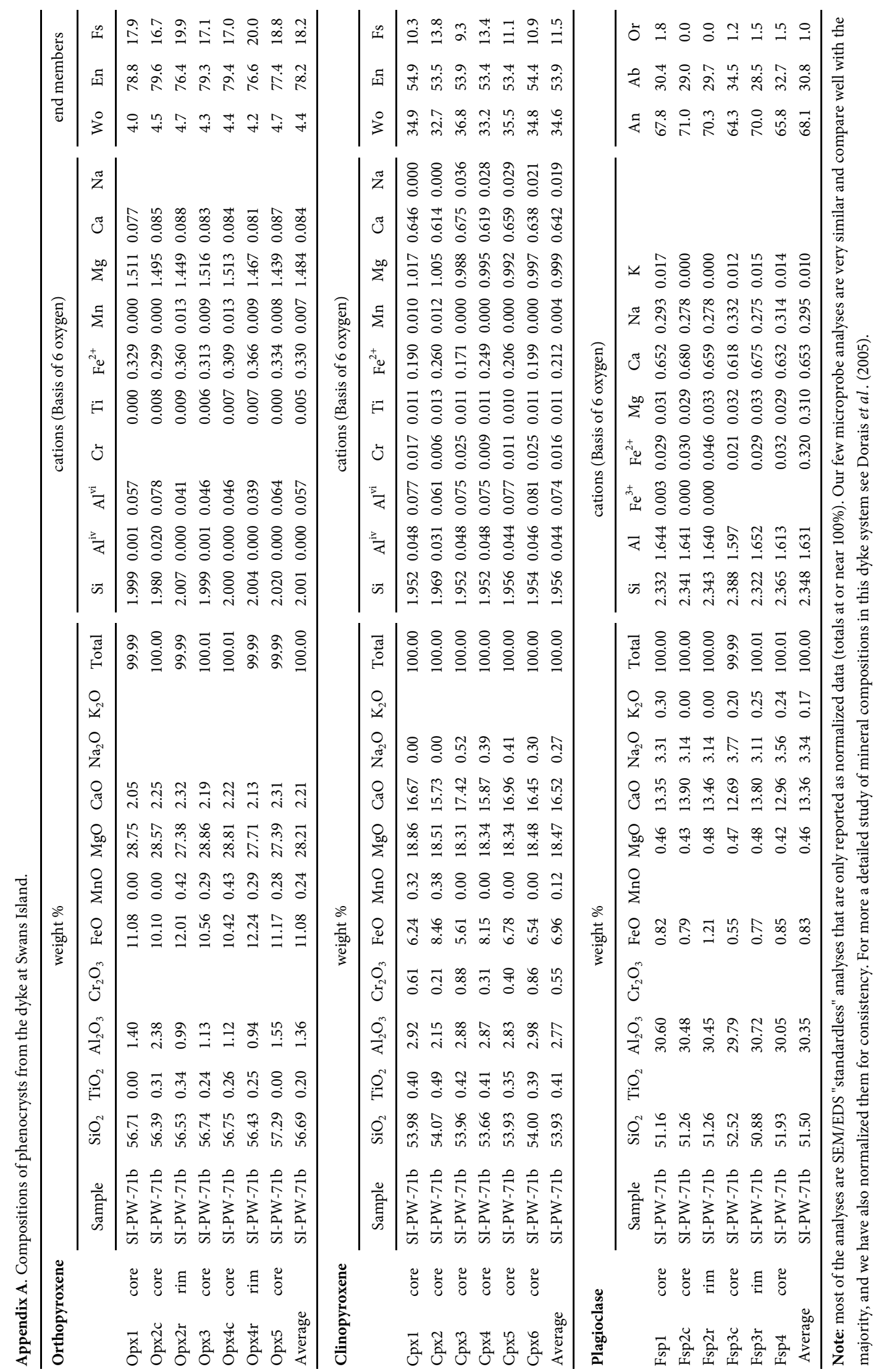


Appendix B: continued.

\begin{tabular}{|c|c|c|c|c|c|c|c|c|}
\hline \multicolumn{9}{|c|}{ Sample: SP - 1 (Christmas Cove Dyke), J-value $=0.006253$} \\
\hline Temp ${ }^{\circ} \mathrm{C}$ & ${ }^{40} \mathrm{Ar} /{ }^{39} \mathrm{Ar}$ & ${ }^{37} \mathrm{Ar} /{ }^{39} \mathrm{Ar}$ & ${ }^{36} \mathrm{Ar} /{ }^{39} \mathrm{Ar}$ & Moles ${ }^{39} \mathrm{Ar}$ & $\%$ Total & $\% \mathrm{Rad}$ & $\mathrm{K} / \mathrm{Ca}$ & Age (Ma) \\
\hline 660 & 88.511 & 3.1490 & 0.21871 & 4.3 & 1.1 & 27.1 & 0.162 & $253.9 \pm 5.3$ \\
\hline 785 & 26.032 & 3.3465 & 0.02434 & 51.2 & 12.5 & 73.2 & 0.146 & $203.9 \pm 2.7$ \\
\hline 880 & 22.954 & 3.8914 & 0.01515 & 60.2 & 14.7 & 81.4 & 0.126 & $200.7 \pm 2.3$ \\
\hline 975 & 21.159 & 3.7523 & 0.01030 & 54.7 & 13.4 & 86.8 & 0.130 & $196.9 \pm 2.0$ \\
\hline 1050 & 20.393 & 3.0286 & 0.00775 & 68.4 & 16.7 & 89.8 & 0.161 & $196.1 \pm 1.9$ \\
\hline 1130 & 20.593 & 2.6849 & 0.00825 & 49.7 & 12.2 & 89.0 & 0.181 & $196.3 \pm 1.9$ \\
\hline Fuse & 24.582 & 9.0482 & 0.01917 & 119.8 & 29.3 & 79.8 & 0.054 & $210.0 \pm 2.0$ \\
\hline \multicolumn{9}{|c|}{ Total gas age $=196.4 \pm 2.8 \mathrm{Ma}$} \\
\hline \multicolumn{9}{|c|}{ Isotope correlation age $=196.4 \pm 3.0 \mathrm{Ma}\left({ }^{40} \mathrm{Ar} /{ }^{36} \mathrm{Ar}\right.$ intercept $\left.=326.9\right)$} \\
\hline \multicolumn{9}{|c|}{ Average age $=197.0\left(57 \%\right.$ of ${ }^{39}$ Ar released $)$} \\
\hline
\end{tabular}

*All samples were analyzed as whole rock splits after sieving to a 100 to 150 micron grain size and after any carbonate minerals were dissolved through washing with warm dilute hydrochloric acid. These samples, along with an internal flux monitor (SBG-7 = 240.9 Ma relative to MMhb-1), were wrapped in Sn foil, sealed in silica glass vials and irradiated in the L67 facility of the Ford Nuclear Reactor at the University of Michigan. Purification of the gases extracted from the flux monitors and unknowns follow standard laboratory procedures described in detail by West et al . (1992). The isotopic composition of argon was measured in 1995 using a Nuclide 6-60 SGA 1.25 mass spectrometer at the University of Maine. Corrections were made for all interfering isotopes produced during irradiation using correction factors determined from irradiated $\mathrm{K}$ and Ca salts. The uncertainty in the calculated J values is believed to be less than $0.5 \%$. Individual ages and uncertainties ( 2 sigma) were calculated using the decay constants and isotope abundances recommended by Steiger and Jager (1977) and the equations given by Dalrymple et al. (1981). Total gas ages represent weighted averages based upon the amount of ${ }^{39} \mathrm{Ar}$ in each increment. Criteria for the determination of plateau ages are from Fleck et al . (1977) and uncertainties associated with the reported plateau ages are two standard deviations about the mean plus an uncertainty in the J-value (estimated at $0.5 \%)$. For convenience, where the apparent ages of consecutive increments are similar but do not satisfy the formal criteria for a plateau age, a weighted average age for the consecutive steps is reported. 
Appendix B: ${ }^{40} \mathrm{Ar} /{ }^{39} \mathrm{Ar}$ analytical data from whole rock dyke samples $\left(\text { moles }{ }^{39} \mathrm{Ar} \times 10^{-13}\right)^{*}$.

\begin{tabular}{ccccccccc}
\hline Temp ${ }^{\circ} \mathrm{C}$ & ${ }^{40} \mathrm{Ar} /{ }^{39} \mathrm{Ar}$ & ${ }^{37} \mathrm{Ar} /{ }^{39} \mathrm{Ar}$ & ${ }^{36} \mathrm{Ar} /{ }^{39} \mathrm{Ar}$ & Moles $^{39} \mathrm{Ar}$ & $\%$ Total & \% Rad & K/Ca & Age (Ma) \\
\hline \multicolumn{7}{l}{ Sample: Ban } \\
\multicolumn{6}{c}{ 1 (Caraquet Dyke), J-value $=0.006421$} \\
660 & 55.177 & 3.7475 & 0.12614 & 8.7 & 2.9 & 33.0 & 0.130 & $199.7 \pm 15.0$ \\
785 & 26.676 & 4.3372 & 0.02840 & 34.6 & 11.7 & 69.8 & 0.113 & $204.2 \pm 2.9$ \\
880 & 22.350 & 5.6259 & 0.01476 & 57.8 & 19.4 & 82.4 & 0.087 & $202.4 \pm 2.4$ \\
975 & 21.114 & 5.8502 & 0.01106 & 56.6 & 19.1 & 86.6 & 0.083 & $201.1 \pm 2.4$ \\
1050 & 20.950 & 5.4912 & 0.01053 & 49.7 & 16.8 & 87.0 & 0.088 & $200.7 \pm 2.2$ \\
1130 & 21.271 & 4.9834 & 0.01125 & 32.8 & 11.1 & 86.0 & 0.096 & $201.3 \pm 2.1$ \\
Fuse & 23.493 & 16.355 & 0.02267 & 56.5 & 19.1 & 76.9 & 0.030 & $200.3 \pm 2.1$
\end{tabular}

Total gas age $=201.7 \pm 3.2 \mathrm{Ma}$

Isotope correlation age $=201.8 \pm 1.7 \mathrm{Ma}\left({ }^{40} \mathrm{Ar} /{ }^{36} \mathrm{Ar}\right.$ intercept $\left.=294.9\right)$

Plateau age $=201.2 \pm 2.6 \mathrm{Ma}\left(66 \%\right.$ of ${ }^{39} \mathrm{Ar}$ released $)$

$\begin{array}{ccccccccc}\text { Sample: HPK }-1 \text { (Higganum Dyke), J-value }=0.006467 \\ 660 & 45.344 & 11.5080 & 0.08925 & 24.1 & 7.1 & 43.8 & 0.042 & 219.8 \pm 6.0 \\ 785 & 23.087 & 4.3202 & 0.01708 & 43.0 & 12.7 & 79.5 & 0.113 & 203.0 \pm 4.8 \\ 880 & 21.826 & 5.5626 & 0.01335 & 58.5 & 17.3 & 83.9 & 0.088 & 202.6 \pm 2.5 \\ 975 & 21.192 & 5.7969 & 0.01161 & 56.5 & 16.7 & 85.9 & 0.084 & 201.6 \pm 2.6 \\ 1050 & 21.197 & 5.3088 & 0.01136 & 45.7 & 13.5 & 86.0 & 0.092 & 201.9 \pm 2.0 \\ 1130 & 21.507 & 4.8019 & 0.01279 & 42.0 & 12.4 & 83.7 & 0.102 & 200.2 \pm 1.9 \\ \text { Fuse } & 23.138 & 12.9360 & 0.01772 & 68.6 & 20.3 & 81.7 & 0.038 & 210.0 \pm 2.1\end{array}$

Total gas age $=204.6 \pm 3.0 \mathrm{Ma}$

Isotope correlation age $=200.2 \pm 2.8 \mathrm{Ma}\left({ }^{40} \mathrm{Ar} /{ }^{36} \mathrm{Ar}\right.$ intercept $\left.=318.7\right)$

Plateau age $=201.7 \pm 2.8 \mathrm{Ma}\left(60 \%\right.$ of ${ }^{39} \mathrm{Ar}$ released $)$

\begin{tabular}{ccccccccc}
\multicolumn{2}{c}{ Sample: DP -1 (Christmas Cove Dyke), J-value $=0.006092$} \\
660 & 50.750 & 2.8950 & 0.10638 & 13.0 & 3.9 & 38.4 & 0.171 & $203.2 \pm 5.3$ \\
785 & 28.394 & 4.0072 & 0.03270 & 41.9 & 12.5 & 67.0 & 0.122 & $198.5 \pm 4.6$ \\
880 & 25.296 & 4.7518 & 0.02220 & 35.9 & 10.7 & 75.5 & 0.103 & $199.2 \pm 4.8$ \\
975 & 23.813 & 5.2994 & 0.01689 & 60.3 & 17.9 & 80.7 & 0.095 & $200.5 \pm 2.3$ \\
1050 & 22.961 & 4.1600 & 0.01116 & 54.0 & 16.1 & 87.0 & 0.177 & $207.9 \pm 2.0$ \\
1130 & 22.927 & 4.0858 & 0.01211 & 55.3 & 16.4 & 85.6 & 0.122 & $204.6 \pm 2.1$ \\
Fuse & 25.068 & 14.0980 & 0.02097 & 75.7 & 22.5 & 79.6 & 0.034 & $209.1 \pm 2.5$
\end{tabular}

Total gas age $=205.3 \pm 3.1 \mathrm{Ma}$

Isotope correlation age $=203.6 \pm 2.6 \mathrm{Ma}\left({ }^{40} \mathrm{Ar} /{ }^{36} \mathrm{Ar}\right.$ intercept $\left.=288.4\right)$

Average age $=203.1\left(61 \%\right.$ of ${ }^{39} \mathrm{Ar}$ released $)$

\begin{tabular}{|c|c|c|c|c|c|c|c|c|}
\hline \multicolumn{9}{|c|}{ Sample: MR - 1 (Christmas Cove Dyke), J-value $=0.006733$} \\
\hline 660 & 41.966 & 4.4992 & 0.07478 & 12.0 & 3.2 & 48.2 & 0.109 & $230.8 \pm 8.9$ \\
\hline 785 & 25.804 & 3.1368 & 0.02563 & 34.2 & 9.0 & 71.5 & 0.156 & $211.8 \pm 3.7$ \\
\hline 880 & 21.350 & 4.3602 & 0.01256 & 35.4 & 9.4 & 84.2 & 0.112 & $206.6 \pm 4.6$ \\
\hline 975 & 20.693 & 4.8337 & 0.00981 & 52.5 & 13.9 & 87.8 & 0.101 & $208.8 \pm 2.5$ \\
\hline 1050 & 20.094 & 3.9068 & 0.00755 & 85.5 & 22.5 & 90.4 & 0.125 & $208.6 \pm 2.2$ \\
\hline 1130 & 20.172 & 3.2905 & 0.00772 & 49.7 & 13.1 & 89.9 & 0.149 & $208.3 \pm 2.4$ \\
\hline Fuse & 23.394 & 10.0790 & 0.01325 & 109.6 & 28.9 & 86.6 & 0.048 & $232.3 \pm 2.5$ \\
\hline \multicolumn{9}{|c|}{ Total gas age $=214.8 \pm 3.0 \mathrm{Ma}$} \\
\hline \multicolumn{9}{|c|}{ Isotope correlation age $=204.8 \pm 2.7 \mathrm{Ma}\left({ }^{40} \mathrm{Ar} /{ }^{36} \mathrm{Ar}\right.$ intercept $\left.=325.6\right)$} \\
\hline \multicolumn{9}{|c|}{ Average age $=208.1\left(59 \%\right.$ of ${ }^{39} \mathrm{Ar}$ released $)$} \\
\hline
\end{tabular}

